Exploring the content and delivery of relationship skills education programmes for adolescents: a systematic review

Astrid Janssens*a, b, Sharon Blake ${ }^{b}$, Matt Allwood ${ }^{c}$, Jan Ewings ${ }^{d}$ and Anne Barlow ${ }^{d}$

a User Perspectives, Institute of Health Research, University of Southern Denmark, Denmark, ${ }^{b}$ Child Health, University of Exeter Medical School, University of Exeter, UK; ${ }^{c}$ Department of Psychiatry, University of Oxford, Oxford, UK; ${ }^{d}$ School of Law, University of Exeter, UK

*Corresponding Author: Astrid Janssens, email: ajanssens@health.sdu.dk 


\section{Abstract}

This paper reviews published research and grey literature on education programmes which aim to teach young people aged between 11 and 18 skills to develop and maintain healthy intimate relationships. Programmes focussing solely on sexual (risky) behaviour, HIV prevention or partner violence were not the focus of this review and thus excluded. Systematic searches were conducted and 76 English language programmes were reviewed, with 17 identified as meeting the inclusion criteria. Characteristics of the included programmes (aims, target audience, content and delivery method) are described. Most programmes were designed to be delivered in school by a teacher covering a broad age range ( 5 years or more) and focused on the intrapersonal and interpersonal dimensions of relationships reflecting adult therapeutic relationship educational models. Future research should focus on further developing and evaluating the content and delivery of relationship skills education programmes grounded in young people's social and cultural context within a framework of human rights.

Keywords: Relationship skills, Programmes, Relationships and Sex Education, systematic review, secondary school students 


\section{Introduction}

'And they called it puppy love; Oh I guess they'll never know. How a young heart really feels [...] Just because we're seventeen.' (Anka 1960). There might have been more truth to these lyrics than 'just another pop song on the heartache of a teenage love story,' as developmentalists have made a case that adolescent romance carries developmental currency for the more serious relationships characteristic of adulthood (Meier and Allen 2008).

Relationships impact a vast array of outcomes (including educational attainment, parenting, crime and antisocial behaviour) and have been accepted as a core social determinant of health and wellbeing (Handley et al. 2015). A wellbeing survey in the UK found that overall satisfaction with life and personal relationships are related; those who reported a medium to high satisfaction with life, also reported medium to high satisfaction with their personal relationships (Oguz, Merad and Snape 2013). In addition, there is a growing evidence base showing relationship distress to be associated with key areas of public health such as alcohol misuse, obesity, depression, mental health issues and child poverty (Coleman, Glenn, and One Plus One 2009; Harold and Leve 2012; Levitt and Cooper 2010; Overbeek et al. 2006). People who live in distressed and troubled relationships are three times more likely to suffer from mood disorders, two and a half times more likely to suffer from anxiety disorders, and twice as likely to misuse substances (Hewison, Clulow, and Drake 2014).

However, it is only in recent years that the serious human and financial cost of relationship breakdown to individuals and society has drawn attention to how policies promote and sustain fulfilling intimate relationships (Handley et al. 2015). Rather than prioritising healthy relationships throughout the life course, relationship support tends only to be available for existing relationships which are already in difficulty. Early intervention may be more likely to improve relationship quality, normalise helpseeking behaviour and prevent relationship breakdown (Markman and Rhoades 2012; Rhoades and Stanley 2009; Walker 2012). This recognition has prompted a move from tertiary to primary intervention both in the USA, where $\$ 75$ million is provided to fund Healthy Marriage Relationship Education (HMRE) programmes each year (US

Department of Health and Human Services 2018), and in England, where following the enactment of sections 34 and 35 of the Children and Social Work Act 2017, Relationships and Sex Education (RSE) becomes mandatory in secondary school curriculum from September 2020 (HM Government 2017).

Due to the existing organisational, social and communication structures and their reach of young people across the social spectrum, schools are in a unique position to provide primary intervention. From tackling obesity (Lloyd et al. 2018) to improving students' social skills (DiPerna et al. 2018) and preventing depression (Perry et al. 2017), the role of the school is widely implicated in recent initiatives with varying success. Incorporating relationship education into the school curriculum provides an opportunity to equip young people with the knowledge and skills required for a healthy intimate relationship. However, public health policies are often perceived as low priority in education policy and 'squeezed off the timetables in many schools' (Hayman 2014). As RSE can be particularly contentious with complex and contradictory norms regarding the expression of sexuality in contemporary society, decisions regarding what to teach in respect of relationship education can be challenging. While 
the US HMRE and the UK RSE guidance includes indicators as to the characteristics of healthy relationships (for example communication, conflict resolution, parenting and financial management skills), both anticipate educators will select and adapt content to fit their local contexts (Pound et al. 2017; Hawkins and Ooms 2012; Department for Education 2019). Despite research showing that unless you get the delivery right, young people will disengage from RSE, little if no guidance is provided on how RSE should be taught (such as frequency, duration, class composition).

Numerous systematic reviews have been carried out looking at the delivery and effectiveness of sex education programmes (See for example: Cushman et al. 2014; Mason-Jones et al. 2016; Poobalan et al. 2009); the programmes reviewed primarily have an aim to delay sexual initiation, reduce STIs, unintended pregnancy or domestic violence. Studies have found that programmes which use interactive, participatory learning and skills-building strategies to promote 'rights-based content, positive, youth-centred messages are effective in empowering adolescents with knowledge and tools required for healthy sexual decision-making and behaviours' (Hall et al. 2016). A recent meta-analysis including sixteen studies looked at the efficacy of four US youth relationship curricula for 15-18 year olds (McElwain, McGill, and Savasuk-Luxton 2017). Wider recent systematic reviews of the content and delivery of programmes which aim to teach young people how to develop a positive, healthy intimate relationship are lacking. The current review aims to identify existing programmes which teach relationship skills for young people aged 11 to 18, exploring their content and delivery methods. Relationship education may be taught separately to sex education or on an integrated basis known as sexuality education or relationship and sex education (RSE). Reflecting an integrated position, throughout this paper we will refer to RSE.

\section{Aim and Objectives}

The aim of this review was to answer the research question: What English language educational programmes are available to teach young people aged 11 to 18 skills required for healthy intimate relationships? More specific objectives were to:

- Identify educational tools aimed at young people aged between 11 and 18 years old that teach skills to develop and/or nurture intimate relationships.

- Describe the aim and target audience of the identified programme, the skills taught \& method of delivery.

- Explore patterns and any gaps in content and delivery of identified RSE programmes.

\section{Method}

This systematic review was carried out following the general principles published by the UK National Health Service Centre for Reviews and Dissemination (Centre for Reviews and Dissemination 2008) and the Preferred Reporting Items for Systematic Reviews and Meta-Analyses (PRISMA) guidelines (Liberati et al. 2009).

\section{Search Strategies}


A search strategy was designed using a combination of MeSH and free-text terms for the PsychINFO database, which was then adapted for other databases. Search terms were grouped (terms for young people, terms for relationships and generic names for programmes), combined with a Boolean OR command and then searched in combination using a Boolean AND command. An example of the search strategy (for MEDLINE) is shown in online Appendix A. Ten electronic databases were searched during March 2017, and updated in March 2018, with the search limited to English language records published from 1997. The search was date restricted as it was agreed that due to social changes, programmes delivered prior to this date are likely to have little relevance today. The databases searched were:

- ASSIA (ProQuest)

- Australia Education Index (ProQuest)

- British Education Index (EBSCO)

- CINAHL (EBSCO)

- The Cochrane Library

- Education Research Complete (EBSCO)

- Educational Resource Information Centre (ERIC) (EBSCO)

- MEDline (OvidSP)

- PsychINFO (OvidSP)

- Web of Science

An Internet search via the Google search engine was also undertaken independently by two researchers using the following terms 'relationship' AND 'skills' AND 'school' OR 'young people' OR 'child*'. Citations were followed where the records retrieved referred to relationship education programmes but did not describe the programmes therein.

\section{Inclusion and Exclusion Criteria}

Inclusion/exclusion criteria were specified and documented in advance in a protocol for the review as per Table 1. We utilised a broad definition of RSE; programmes were included in the review if they were offered as relationship education (RE), as well as those offered as RSE (including focused content on both RE topics and sexuality/sexual intimacy). Programmes that only had a small component of relationship skills in their curriculum were excluded.

[Table 1 about here]

\section{Programme Selection}

After duplicates had been removed, the results of the database search were divided into equal groups alphabetically by the first author of the record in an Endnote library. Two groups of reviewers (SB and MA, AJ and TR/ET) independently screened all titles and abstracts to identify records in which potentially eligible programmes were cited. To check screening consistency, a reviewer from Group 1 (SB) then screened 10\% of the records screened by Group 2 and vice versa (TR/ET). Discrepancies were discussed 
and resolved within the team with the arbitration of the project lead (AJ) where necessary. Programmes identified from the Internet search were considered by three of the review team and exclusion/inclusion agreed by consensus ( $A J, S B, M A)$.

Where a record mentioned a programme that met the inclusion criteria, or it was unclear from title and abstract whether it met the criteria, the full journal article text was retrieved. These full texts were then split into two groups alphabetically by first author and two reviewers (MA, SB) independently screened the records against the inclusion/exclusion criteria. A third reviewer (AJ) then double-screened $10 \%$ of the records of each of these groups to check for consistency and any queries were discussed and resolved.

Identified programmes were investigated further via an Internet search and checking of programme deliverer's website to collect details about the programme. Data about the programmes was extracted from the identified records to enable a narrative synthesis presented below.

\section{Theoretical Framework guiding data extraction and synthesis}

This review aims to provide information about existing programmes offering relationship education. Following United Nations Educational, Scientific and Cultural Organization's (UNESCO) advice, which advocates for education as a human right, we discuss the identified programmes through a humanistic lens (Bartholomew Eldrigde et al. 2016). UNESCO articulate a unifying vision for education that leaves room for cultural diversity in contrast to the pragmatic "one size fits all" models exemplified by Education for All (EFA) and the Organisation for Economic Co-operation and Development's (OECD) performance surveys that dominate some of the global education discourse (Sobhi and UNESCO Education Sector 2015). A humanistic lens to education is based on the foundation of an integrated approach to knowledge, learning and development which recognises the diversity of knowledge systems, worldviews and conceptions of well-being as a source of wealth (Gage and Berliner 1991; DeCarvalho 1991).

Data extraction was also guided by Pound et al (2017) and Poobalan et al. (2009); whose work identified key characteristics which make relationship and sex education programmes effective, acceptable, sustainable and capable of faithful implementation. These key characteristics of good practice are largely congruent with a humanistic model of education: adaptable; appropriate to participants' age, cultural and sexual experience; uses a spiral curriculum (repeated throughout the schoolcurriculum) with age-appropriate stages; of sufficient duration and intensity; interactive and engaging; and delivered in a safe and confidential setting.

Inductive thematic coding enabled us to identify and categorise these similar concepts such that we could record the presence or absence of a skill for each programme. This work was undertaken by one researcher (SB) and audited by two other researchers (AJ, MA). The data extraction form was developed by one reviewer (AJ) and then revised after applying it to a small number of programmes and by discussion with the group. The extracted data were presented using the following headings: programme aims, target audience, relationship skills taught, programme delivery method and setting, duration and materials used. 


\section{Results}

The PRISMA flowchart in Figure 1 shows the search and selection process. The electronic database search yielded 7026 unique records and from this, 76 programmes were initially identified as potentially eligible. Further review of these programmes via citation chasing and web searches resulted in the identification of 10 programmes which met the inclusion criteria. The Internet search identified 14 webpages describing a relationship skill education programme and 1 non-peer reviewed systematic review of relationship programmes (Scott et al. 2012). The programmes described within the Scott et al. (2012) review and the webpages were screened and a total of 10 programmes from the Internet search were identified as meeting the inclusion criteria. Three of these had also been identified by the database search, meaning that a total of 17 programmes aimed at young people aged between 11 and 18 years old that teach skills to develop and/or nurture intimate relationships were found.

[Figure 1 about here]

Table 2 summarises the characteristic of the included programmes. Access to information and the comprehensiveness of detail about the programme varied, the results therefore are based on the information available at the time via the source detailed in Table 2.

[Table 2 about here]

The Table in online Appendix B provides information about the 59 programmes which were excluded. Twenty-nine programmes were excluded due to focus on sexual health, 17 due to focus on relationship violence, 8 for not teaching relationship skills, 4 for not targeting a broad 11 to 18 age-range and 1 described a programme of work rather than an individual programme.

\section{Included Programme Characteristics}

Eleven of the included programmes were developed in the USA, two in the UK, two in Australia and one in Austria. 'It's All One Curriculum' from the Population Council was the result of an international collaboration and has been translated into Spanish, French, Bangla, Chinese and Arabic with requests for the programme coming from over 150 countries and every state of the USA (Haberland et al. 2009).

From looking at the dates of publication, programmes appear to vary in how established they are. 'Connections: Relationships and Marriage' had a publication published about the programme in 2003, while the webpages providing information for two programmes ('Growing Respect' and 'Positive Choices') suggest they are still at design-stage.

\section{Programme Aims}

Eight of the seventeen programmes aim to generally promote healthy relationships. 'Teen Choices', 'Positive Choices', 'DO' and 'It's All One Curriculum' are centred more around making healthy sexual choices while also outlining skills of healthy 
relationships. Reflecting the adolescent targeted audience, some of the programmes focus more on initiating relationships, with one of the programmes promoting abstinence ('Choosing the Best'). Five of the programmes pay particular attention to long-term relationships ('Choosing the Best', 'Connections: Relationships \& Marriage', 'PICK', 'The Art of Loving Well' and 'What's Real'). Most of the programmes are careful to describe a variety of different long-term committed relationship forms rather than singularly promote marriage. 'PICK' has an optional bible study element and describes itself as harmonious with Christian principles.

From the information reviewed, only two of the included programmes describe the theoretical underpinning of the design of the intervention. 'Connections: Dating \& Emotions' is described as being based on Erikson's Stages of Psychosocial Development (https://www.dibbleinstitute.org/connections-dating-and-emotionsdetails/). 'Teen Choices' is described as being based on Transtheoretical Model of behaviour change (Levesque et al. 2016).

\section{Target Audience}

Fifteen of the seventeen included programmes are designed to be delivered to ages 11 to 18. Two programmes target a slightly older age-group: 'Connections: Relationships and Marriage' for age 16 to 21 and 'What's Real' for age 13 to 21. Two programmes provide different versions for age ranges within the inclusion criteria: 'Growing Respect' has a version for 10 to 13 year olds and a version for 15 to 16 year olds, 'Choosing the Best' has a version for 14 to 16 year olds and 16 to 18 year olds. While 'Healthy Choices, Healthy Relationships' acknowledges developmental differences and differences in social messages for girls and boys, from the information reviewed, none of the included programmes separate activities by gender or include specific activities focused on lesbian, gay, bisexual, transgender (LGBT) relationships.

\section{Relationship Skills Taught}

A wide variety of skills were extracted; the most popular skills that the included programmes sought to teach young people were how to recognise healthy relationship patterns (and the converse unhealthy relationship patterns), communication and understanding yourself/goal setting (identifying personal values and aspirations). Most of the programmes included information to improve knowledge of appropriate relationship progression, including how sex affects relationship dynamics and how to notice predecessors to abusive behaviour. In addition, six relationship programmes specifically explored the effect of media on relationship expectations.

More than half of the programmes included content to build inner resources (such as resilience and self-confidence), interpersonal attributes (such as respect, trust and empathy) and life-skills. In relation to life-skills, the most popular was decisionmaking/critical thinking skills (featured in eight programmes). Only a few programmes looked at other life skills such as problem-solving or negotiation, and only one programme ('Connections: Relationships and Marriage') included content on everyday practical skills, in this instance financial management, which can be a source of conflict in a relationship. In relation to conflict in relationships, more programmes appeared to focus on skills to resolve rather than prevent or reduce conflict. 
Two programmes ('DO', 'It's All One Curriculum') look at sexuality and along with 'Love U2: Relationship Smart' promote the use of inclusive sexual orientation examples of relationships in their resources. While, these same two programmes, plus 'I Like, Like You', also looked at the effect of gender stereotypes on behaviour.

\section{Programme Delivery and Setting}

The interventions varied widely in their complexity, with educational and behavioural components delivered by a range of activities from games to audio-visual aids. All the included programmes can be delivered to classes within schools with most of the programmes employing classroom-based instruction as their main approach. Most of the programmes involve multiple instructional strategies, often a combination of direct methods such as role-play and discussion, technology-based methods such as PowerPoint slides and films and student diaries to complete during the sessions and to take home. Three of the programmes describe single lesson plans ('Friend Flips', 'Love House' and 'Relationship Building Blocks'). 'Teen Choices' is the only programme delivered solely online so can be run anywhere with internet access. However, like all the included programmes, it is primarily implemented within schools.

Some of the activities described within the programmes suggest that teachers/facilitators split the group into smaller groups of four/five young people. However, none of the programmes appear to specify a recommended group size for the programme.

Most of the programmes are designed to require minimal preparation with lesson plans and instruction manuals provided. A trained teacher is commonly described as the facilitator although programme handbooks can be utilised by youth leaders, community groups and in one case, 'PICK' can be used within youth prisons. Two programmes provided facilitator training, and one other signposted to training: 'PICK' and 'Choosing the Best' require the facilitator to be trained and certified to deliver the programme; 'DO' has self-reflection exercises for the programme facilitator and provides links to sources of further training for relationship educators. Only one programme, 'I Like, Like You', is delivered by a trained facilitator who works with the class teacher.

'Positive Choices' is the only programme that has a student-led optional element; none of the other programmes include a peer-to-peer component.

The 'PICK' and 'Love U2: Relationship Smart' programmes provide resources for parents to follow-up on relevant discussions at home. 'Choosing the Best' provides a handbook for parents to deliver the course to young people at home.

\section{Duration}

Thirteen of the included programmes were designed to have sessions lasting around an hour. 'Teen Choices' is the only programme to specify shorter 25 to 30-minute sessions. The number of sessions ranged from one one-off session ('Friend Flips') to eighteen one-hour sessions ('Connections: Relationships and Marriage'). Four of the programmes do not provide a specific time frame, with duration depending on student progression or as in the case of 'Positive Choices' to be ongoing over a period of one to two years. 


\section{Materials}

The majority of included programmes provide an instructor handbook which outlines lesson content, activities and required materials so they can be delivered by various facilitators in different settings. Almost all programmes require the use of standard classroom materials such as flip chart paper, coloured pens and in some cases interactive whiteboards. The instructor handbooks sometimes include a training DVD or $\mathrm{CD}$ which also may have electronic versions of student materials and/or visual aids to be used in the session. The range of materials provided to use within the sessions to stimulate discussion and develop skills range from journals for the student to work through, flip cards, games, case studies, film-clips, physical blocks to stack and song lyrics. The 'Teen Choices' programme is the only web-based multimedia learning platform programme which is solely completed using a computer.

\section{Discussion}

This review aimed to provide an overview of programmes focusing on skills that would allow young people aged 11 to 18 to develop and sustain a healthy intimate relationship. Our search revealed that most programmes focus on the prevention of unplanned or teenage pregnancy, transmission of HIV or sexually transmitted infections or violent relationships (see Table with excluded programmes). The finding is not surprising in the light of a recent review of reviews of school-based sexual-health and relationship education programmes (Denford et al. 2017). The review categorised evaluated interventions into five types; three of the five categories were abstinenceonly or pregnancy or HIV prevention programmes. A fourth category, dealing with comprehensive interventions, included programmes that 'aim to prevent, stop, or decrease sexual activity, but also promote condom use and other safer-sex strategies as alternatives for sexually active participants' (Denford et al. 2017) again showing a narrow focus on sexual-risk prevention.

This is the first review to present a list of available programmes which promote healthy relationships or healthy sexual choices while also outlining skills for healthy relationships. We identified 17 programmes and described these according to evidence-based characteristics of successful implementation using a humanist approach to education. Perhaps reflecting different governance requirements in different countries, some of the included programmes took an integrated RSE approach whilst others aimed to address relationship skills separate to sex education.

\section{Age appropriateness and class composition}

Only two programmes provided different versions for different age ranges between 11 and 18 years, suggesting gaps in current RSE resources which target smaller sections of this broad age range. Research indicates that gender-focused programmes are more effective than gender-blind programmes at achieving health outcomes such as reducing rates of unintended pregnancy (UNESCO 2018). None of the included programmes split any activities by gender and future research is needed to explore gender-based delivery of RSE. 


\section{Delivery method, setting and duration}

The selected programmes perform slightly better with regards to delivery; most programmes use a combination of educational strategies. Passive instruction through mainstream lecture-type teaching or the use of films was a feature of many of the included programmes. Yet, the majority used multiple instructional strategies including interactive methods such as group discussion or role-play, educational strategies that are associated with more effective interventions (Poobalan et al. 2009; Pound et al. 2017; Robin et al. 2004).

Although evidence for effective programmes is weighted towards population interventions (Saunders and Smith 2016) and the school is a logical place for universal programmes, it is striking that all are primarily designed to be delivered in school and few of these programmes target a different learning environment. The duration and intensity of these programmes varied from a single session to eighteen one-hour sessions, often with no rationale for the duration. Best practice suggests spiral curriculums where groups return to the same topics to reinforce learning and give time to practice skills, plus special events, multiple teaching methods and external experts to facilitate RSE (Pound et al. 2017). Only one programme continued over a period of two years.

Despite research showing that many young people dislike having their teachers deliver relationship and sex education due to an imbalance of power, lack of confidentiality and awkwardness (Pound, Langford, and Campbell 2016), all but one of the programmes recommended a trained teacher as facilitator. While there is mixed evidence for the effectiveness of peer-led or peer-supported school-based interventions (Chin et al. 2012; Sebire et al. 2016), a peer-delivery system is often welcomed by young people (White et al. 2017). However, only one programme had a student-led optional element. Many teachers may not feel skilled to deliver RSE (Pound et al. 2017). Adequate training of personnel delivering interventions has been identified as important facilitators of effectiveness (Poobalan et al. 2009). Of seventeen programmes, three provided or signposted to facilitator training and only one provided their own facilitator. Often, lack of resources will prevent schools engaging an external educator and even if an outside speaker is brought in, a teacher will often need to remain with the group. However, tasking teachers with the delivery of RSE can compromise their role which is constructed as desexualised. Outsourcing the delivery will protect the setting and protect student confidentiality and create a safe environment to discuss and share personal experiences.

The World Health Organisation (WHO) Health Promoting School framework advocates school-based interventions which promotes links with families and communities (Langford et al. 2014). Despite growing evidence of parental involvement as a key element of effective interventions, (Langford et al. 2014; Lloyd et al. 2017; Weare and Nind 2011) only two programmes provide resources for parents to contribute to the programme delivery.

\section{Content (skills)}

In respect of relationship skills, most of the programmes focus on the intrapersonal and interpersonal dimensions of relationships. A wide variety of skills were extracted, 
the most popular 'recognising healthy relationship patterns', 'communication' and 'understanding yourself'. This reflects therapeutic interventions for couple relationship which usually address: common relationship pitfalls, conflict management, active listening, problem-solving, shared relationship expectations, positive relationship activities, acceptance, empathy and individual self-regulation (Whitton and Buzzella 2012).

In line with the expressed concern for young people growing up in an increasing complex and digital world (Department for Education 2017), many of the relationship programmes explore the effect of media on relationship expectations, encouraging young people to critically reflect on their understanding of what constitutes a healthy relationship. However, the wide range of interconnected social factors including gender norms and inequities, poverty, exclusion and legal frameworks which influence relationships is lacking in these programmes (Pound, Langford, and Campbell 2016). Young people have observed that RSE is gendered and heterosexist (Pound, Langford, and Campbell 2016) and have advocated for an inclusive approach (Coll, O'Sullivan, and Enright 2018). Our findings indicate support for the general trend in RSE for LGBT-related information about healthy relationships to be largely excluded (e.g. Department for Education 2019).

While a core set of components may be appropriate for heterosexual and homosexual relationship education, the presentation of these components may require modification to remove heterosexual bias (Whitton and Buzzella 2012). International guidance on sexuality education promotes delivery within a framework of human rights and gender equality to support students to question social and cultural norms (European Expert Group on Sexuality Education 2016; UNESCO 2018). From an examination of US programme curricula (Bay-Cheng 2003), it was suggested that US RSE 'reifies narrow definitions of normal teen sex as heterosexual and coital...[and] fails to address the interplay among gender, race, class and sexuality'. Aside from 'It's all one curriculum', this still does not currently seem to be addressed in the RSE programmes reviewed.

Adolescents are a heterogeneous group in terms of development and the social context in which they live and it is challenging to consider the normative messages behind educational content in pluralist societies. This and the adoption of a medical model paradigm which emphasises individual autonomy and responsibility in respect of healthy intimate relationships may explain why most of the programmes focused only on intrapersonal and interpersonal dimensions (Ballonoff Suleiman and Brindis 2014). Perpetuating the therapeutic aims of couple counselling within RSE programmes for youth ignores how social factors including cohabitation, legal rights myths, poverty and forced marriage influence relationship decisions and outcomes. Expecting individual teachers to have enough understanding of different cultural traditions in relation to relationships in order to tailor interventions and resources may be an ask too far. The programmes that did include content on social aspects of relationships often were those that took a clear position such as the promotion of marriage and/or abstinence. As RSE can provoke substantial resistance from groups who do not feel it represents their values, it is arguably important to provide further guidance to educators on what to deliver and how.

This review aimed to synthesise available educational relationship tools to inform discussion of the content and delivery method of RSE programmes and future 
design of resources. The next step will be to find out what young people want to know and learn prior to engaging in an intimate relationship and what is the most effective way of delivering these skills?

\section{Strengths and limitations}

While the search for programmes was wide, it was limited to English-language publications. As just over half of the included programmes were found outside of the database search via unpublished sources, it is possible that other programmes have been missed. Brands remarketing over time may also mean that some of the programmes listed may be known by another commercial name and / or better presented as one programme. In most cases, to gain a broad overview, descriptions of programme content and delivery were used as sources of information rather than detailed programme manuals. The excluded programmes are listed in online Appendix $B$, so that readers can see what other programmes were found and the reason given for exclusion.

A number of challenges were associated with selecting and synthesising programmes for this review which highlight issues for further consideration in programme development namely sustainability and consistency. It was not always clear whether programmes were still in use or not. This indicates a lack of consistent funding and the importance of evidencing impact to improve programme sustainability. Few programmes described theoretical rationales behind the design or delivery of their programmes. This and the lack of consistent definitions of instructional strategies and skills/components taught made it challenging to make comparisons.

\section{Conclusion}

This systematic review is a first attempt to close the knowledge gap around RSE programmes by identifying existing programmes focusing on developing and establishing healthy intimate relationships. By bringing these together, this review assists in exploring what content and delivery methods are currently promoted.

While the programmes reviewed use a range of activities to teach RSE, they are typically designed for teachers to facilitate, with a lack of resources for targeted ages or spiralling curriculums. The programme content characteristically reflects adult therapeutic relationship educational models, which may be the skills that are needed for a healthy intimate relationship but do not frame the experience within the young person's social and cultural context.

RSE programmes have the capacity to improve young people's skills to build and sustain future strong and stable relationships, and thereby improve their mental and physical health and well-being. Building on the programmes reviewed within, educators, programme-developers, policymakers and researchers can together work towards further developing and evaluating the content and delivery of relationship skills education programmes.

\section{Acknowledgements}


Our thanks go to Fiona Shackleton who funded this research, members of the Evidence Synthesis Team at the University of Exeter Medical School who advised the design of the search strategy, and Abigail Woodley for assistance in running the database searches. The authors thank Ebony Tregent and Tom Reed for assisting the research team with the online search for programme content.

\section{Funding}

This work was supported by an alumnus donation to the University of Exeter from Baroness Shackleton of Belgravia VLO. The funder did not have any involvement in the study or write-up and the views expressed herein are those of the authors only.

\section{Disclosure statement}

The authors declare that there are no further conflicts of interests to declare.

\section{Data availability statement}

The authors confirm that the data supporting the findings of this study are available within the article and associated online supplementary material. 


\section{References}

Adler-Baeder, Francesca, Jennifer L. Kerpelman, David G. Schramm, Brian Higginbotham, and Amber Paulk. 2007. "The Impact of Relationship Education on Adolescents of Diverse Backgrounds." Family Relations 56 (3):291-303.

Anka, Paul. 1960. "Puppy love." In, Paul Anka Sings his Blues [album].. New York, USA: ABC-Paramount.

Ballonoff Suleiman, Ahna, and Claire D. Brindis. 2014. "Adolescent School-Based Sex Education: Using Developmental Neuroscience to Guide New Directions for Policy and Practice." Sexuality Research and Social Policy 11 (2):137-52.

Bartholomew Eldrigde, L. K., C. M. Markham, R. A. C. Ruiter, M. E. Fernàndez, G. Kok, and G. S. Parcel. 2016. Planning health promotion programs: An Intervention Mapping approach (4th ed.). Hoboken, NJ: Wiley.

Bay-Cheng, Laina Y. 2003. "The Trouble of Teen Sex: The construction of adolescent sexuality through school-based sexuality education." Sex Education 3 (1):61-74.

Centre for Reviews and Dissemination. 2008. Systematic Reviews: CRD's Guidance for Undertaking Systematic Reviews in Health Care. York, UK: Centre for Reviews and Dissemination, University of York.

Chin, H. B., T. A. Sipe, R. Elder, S. L. Mercer, S. K. Chattopadhyay, V. Jacob, H. R. Wethington, et al. 2012. "The effectiveness of group-based comprehensive riskreduction and abstinence education interventions to prevent or reduce the risk of adolescent pregnancy, human immunodeficiency virus, and sexually transmitted infections: two systematic reviews for the Guide to Community Preventive Services." American Journal of Preventive Medicine 42 (3):272-94.

Coleman, Lester, and Fiona Glenn. 2009. "When couples part: Understanding the consequences for adults and children." London, UK: One Plus One.

Coll, Leanne, Mary O'Sullivan, and Eimear Enright. 2018. "'The Trouble with Normal': (re)imagining sexuality education with young people." Sex Education 18 (2):157-71.

Cushman, Nicole, Leslie M. Kantor, Elizabeth Schroeder, Lesley Eicher, and Gina Gambone. 2014. "Sexuality education: findings and recommendations from an analysis of 10 United States programmes." Sex Education 14 (5):481-96.

DeCarvalho, Roy José. 1991. "The humanistic paradigm in education." The Humanistic Psychologist 19 (1):88-104.

Denford, Sarah, Charles Abraham, Rona Campbell, and Heide Busse. 2017. "A comprehensive review of reviews of school-based interventions to improve sexual-health." Health Psychology Review 11 (1):33-52.

Department for Education. 2017. "Policy Statement: Relationships Education, Relationships and Sexual Education, and Personal, Social, Health and Economic Education." Available at: https://www.gov.uk/government/publications/relationships-education-rseand-pshe (Accessed 4 June 2018).

Department for Education. 2019. "Relationships Education, Relationships and Sex Education (RSE) and Health Education." Available at: https://www.gov.uk/government/publications/relationships-educationrelationships-and-sex-education-rse-and-health-education (Accessed 7 August 
2019).

DiPerna, James Clyde, Puiwa Lei, Weiyi Cheng, Susan Crandall Hart, and Jillian Bellinger. 2018. "A cluster randomized trial of the Social Skills Improvement System-Classwide Intervention Program (SSIS-CIP) in first grade." Journal of Educational Psychology 110 (1):1-16.

European Expert Group on Sexuality Education. 2016. "Sexuality education - what is it?". Sex Education 16 (4):427-31.

Gage, N., and D. Berliner. 1991. Educational psychology (5th ed.). Boston, MA: Houghton Mifflin Harcourt.

Gardner, Scott P., James G. Bridges, Alicia Johnson, and Hilary Pace. 2016. "Evaluation of the What's Real: Myths \& Facts about Marriage Curriculum: Differential Impacts of Gender." Marriage \& Family Review 52 (6).

Haberland, N, D Rogow, O Aguilar, D Braeken, J Clyde, C Earle, D Kohn, B Madunago, G Osakue, and C Whitaker. 2009. "It's All One Curriculum: Guidelines and Activities for a Unified Approach to Sexuality, Gender, HIV, and Human Rights Education." The Population Council Available at: http://www.popcouncil.org/uploads/pdfs/2011PGY ItsAllOneGuidelines en.pd f (Accessed 13 November 2019).

Hall, Kelli Stidham, Jessica McDermott Sales, Kelli A. Komro, and John Santelli. 2016. "The State of Sex Education in the United States." The Journal of adolescent health : official publication of the Society for Adolescent Medicine 58 (6):595-7.

Handley, Sarah, Iona Joy, Cecilie Hestbaek, and David Marjoribanks. 2015. "The Best Medicine? The importance of relationships for health and wellbeing."London, UK: New Philantrophy Capital and Relate.

Harold, Gordon T., and Leslie D. Leve. 2012. "Parents as partners: How the parental relationship affects children's psychological development." In How couple relationships shape our world: Clinical practice, research, and policy perspectives., edited by Andrew Balfour, Mary Morgan and Christopher Vincent, 25-55. London, UK: Karnac Books Ltd.

Hawkins, Alan J., and Theodora Ooms. 2012. "Can Marriage and Relationship Education Be an Effective Policy Tool to Help Low-Income Couples Form and Sustain Healthy Marriages and Relationships? A Review of Lessons Learned." Marriage \& Family Review 48 (6):524-54.

Hayman, Joe. 2014. "Personal, social, health and economic education: the bridge between public health and education." International Journal of Health Promotion and Education 52 (5):245-9.

Hewison, David, Christopher Clulow, and Harriet Drake. 2014. A guide to couple therapy for depression: A Clinician's Guide to Integrative Practice. Oxford: Oxford University Press.

HM Government. 2017. "Children and Social Work Act 2017." Available at: http://www.legislation.gov.uk/ukpga/2017/16/contents/enacted (Accessed 7 August 2019).

Langford, R., C. P. Bonell, H. E. Jones, T. Pouliou, S. M. Murphy, E. Waters, K. A. Komro, L. F. Gibbs, D. Magnus, and R. Campbell. 2014. "The WHO Health Promoting School framework for improving the health and well-being of students and their academic achievement." The Cochrane Database of Systematic Reviews (4):Cd008958. 
Levesque, D. A., J. L. Johnson, C. A. Welch, J. M. Prochaska, and A. L. Paiva. 2016. "Teen Dating Violence Prevention: Cluster-Randomized Trial of Teen Choices, an Online, Stage-Based Program for Healthy, Nonviolent Relationships." Psychology of Violence 6 (3):421-32.

Levitt, A., and M. L. Cooper. 2010. "Daily alcohol use and romantic relationship functioning: evidence of bidirectional, gender-, and context-specific effects." Personality \& Social Psychology Bulletin 36 (12):1706-22.

Liberati, A., D. G. Altman, J. Tetzlaff, C. Mulrow, P. C. Gotzsche, J. P. Ioannidis, M. Clarke, P. J. Devereaux, J. Kleijnen, and D. Moher. 2009. "The PRISMA statement for reporting systematic reviews and meta-analyses of studies that evaluate healthcare interventions: explanation and elaboration." $B M J$ 339:b2700.

Lloyd, Jenny, Siobhan Creanor, Stuart Logan, Colin Green, Sarah G. Dean, Melvyn Hillsdon, Charles Abraham, et al. 2018. "Effectiveness of the Healthy Lifestyles Programme (HeLP) to prevent obesity in UK primary-school children: a cluster randomised controlled trial." The Lancet Child \& Adolescent Health 2 (1):35-45.

Lloyd, Jenny, Camilla McHugh, Jacky Minton, Helen Eke, and Katrina Wyatt. 2017. "The impact of active stakeholder involvement on recruitment, retention and engagement of schools, children and their families in the cluster randomised controlled trial of the Healthy Lifestyles Programme (HeLP): a school-based intervention to prevent obesity." Trials 18 (1):378.

Markman, H. J., and G. K. Rhoades. 2012. "Relationship education research: current status and future directions." Journal of Marital and Family Therapy 38 (1):169200.

Mason-Jones, A. J., D. Sinclair, C. Mathews, A. Kagee, A. Hillman, and C. Lombard. 2016. "School-based interventions for preventing HIV, sexually transmitted infections, and pregnancy in adolescents." Cochrane Database of Systematic Reviews 11.

McElwain, Alyssa, Julianne McGill, and Rachel Savasuk-Luxton. 2017. "Youth relationship education: A meta-analysis." Children and Youth Services Review 82:499-507.

Meier, Ann, and Gina Allen. 2008. "Intimate relationship development during the transition to adulthood: Differences by social class." New Directions for Child and Adolescent Development 2008 (119):25-39.

Miller, Maryellen B., and Brigitte Cizek. 2006. "Love House." American Journal of Sexuality Education 1 (2):83-8.

Oguz, Sebnem, Salah Merad, and Dawn Snape. 2013. "Measuring National Well-being What matters most to Personal Well-being?"London, UK: Office for National Statistics.

Overbeek, G., W. Vollebergh, R. de Graaf, R. Scholte, R. de Kemp, and R. Engels. 2006. "Longitudinal associations of marital quality and marital dissolution with the incidence of DSM-III-R disorders." Journal of Family Psychology 20 (2):284-91.

Perry, Yael, Aliza Werner-Seidler, Alison Calear, Andrew Mackinnon, Catherine King, Jan Scott, Sally Merry, et al. 2017. "Preventing Depression in Final Year Secondary Students: School-Based Randomized Controlled Trial." Journal of Medical Internet Research 19 (11):e369.

Ponsford, R., E. Allen, R. Campbell, D. Elbourne, A. Hadley, M. Lohan, G. J. Melendez- 
Torres, et al. 2018. "Study protocol for the optimisation, feasibility testing and pilot cluster randomised trial of Positive Choices: a school-based social marketing intervention to promote sexual health, prevent unintended teenage pregnancies and address health inequalities in England." Pilot and Feasibility Studies 4:102.

Poobalan, Amudha S., Emma Pitchforth, Mari Imamura, Janet S. Tucker, Kate Philip, Jenny Spratt, Lakshmi Mandava, and Edwin van Teijlingen. 2009.

"Characteristics of effective interventions in improving young people's sexual health: a review of reviews." Sex Education 9 (3):319-36.

Pound, Pandora, Sarah Denford, Janet Shucksmith, Clare Tanton, Anne M. Johnson, Jenny Owen, Rebecca Hutten, et al. 2017. "What is best practice in sex and relationship education? A synthesis of evidence, including stakeholders' views." BMJ Open 7 (5).

Pound, Pandora, Rebecca Langford, and Rona Campbell. 2016. "What do young people think about their school-based sex and relationship education? A qualitative synthesis of young people's views and experiences." BMJ Open 6 (9).

Rhoades, G. K., and S. M. Stanley. 2009. "Relationship education for individuals: The benefits and challenges of intervening early." In What works in relationship education: Lessons from academics and service deliverers in the United States and Europe., edited by H Benson and S Callan, 44-54. Doha, Qatar: Doha International Institute for Family Studies and Development.

Robin, L., P. Dittus, D. Whitaker, R. Crosby, K. Ethier, J. Mezoff, K. Miller, and K. PappasDeluca. 2004. "Behavioral interventions to reduce incidence of HIV, STD, and pregnancy among adolescents: a decade in review." The Journal of Adolescent Health 34 (1):3-26.

Santabarbara, T., R. Erbe, and S. Cooper. 2009. "Relationship building blocks." Journal of Theoretical Social Psychology 79 (10):505-9.

Saunders, Kate E, and Katharine A Smith. 2016. "Interventions to prevent self-harm: what does the evidence say?" Evidence Based Mental Health 19(3):69-72.

Scott, Mindy E, Kristin Anderson Moore, Alan J Hawkins, Karin Malm, and Martha Beltz. 2012. "Putting Youth Relationship Education on the Child Welfare Agenda: Findings from a Research and Evaluation Review." Child Trend Publications Available at: https://www.childtrends.org/wpcontent/uploads/2013/06/2012-47RelationshipEducFullRpt1.pdf. (Accessed 13 November 2019).

Sebire, S. J., M. J. Edwards, R. Campbell, R. Jago, R. Kipping, K. Banfield, K. Tomkinson, et al. 2016. "Protocol for a feasibility cluster randomised controlled trial of a peer-led school-based intervention to increase the physical activity of adolescent girls (PLAN-A)." Pilot and Feasibility Studies 2:2.

Sobhi, Tawil, and UNESCO Education Sector. 2015. "Rethinking education: towards a global common good?" Available at: http://unesdoc.unesco.org/images/0023/002325/232555e.pdf (Accessed 8 August 2019).

Sparks, Anne, Mingun Lee, and Solveig Spjeldnes. 2012. "Evaluation of the High School Relationship Curriculum Connections: Dating and Emotions." Child and Adolescent Social Work Journal 29 (1):21-40.

Szucs, Leigh, Jovanni V. Reyes, Jennifer Farmer, Kelly L. Wilson, and Elisa Beth McNeill. 
2015. "Friend Flips: A Story Activity about Relationships." American Journal of Sexuality Education 10 (3):261-76.

United Nations Educational, Scientific and Cultural Organization (UNESCO). 2018

"International Technical Guidance on Sexuality Education: An EvidenceInformed Approach." Available at:

http://unesdoc.unesco.org/images/0026/002607/260770e.pdf (Accessed 3 July 2018).

US Department of Health and Human Services. 2018. "Healthy Marriage and Relationship Education: Strengthening Family Bonds and Increasing Economic Independence." Available at: https://www.hhs.gov/blog/2018/08/23/healthymarriage-and-relationship-education.html (Accessed 7 August 2019).

Van Epp, Morgan C., Ted G. Futris, John C. Van Epp, and Kelly Campbell. 2008. "The Impact of the PICK a Partner Relationship Education Program on Single Army Soldiers." Family and Consumer Sciences Research Journal 36 (4):328-49.

Walker, J. 2012. "Commentary on Rhodes, H. 'Her Majesty's department of love? The state and support for couple and family relationships'." In How Couple Relationships Shape our World: Clinical Practice, Research and Policy Perspectives., edited by A Balfour, M Morgan and C Vincent. 269-276.London: Karnac Books.

Walsh, Angela, and Trudi Peters. 2011. "NAPCAN's 'growing respect': A whole-ofschool approach to violence prevention and respectful relationships." Redress 20 (1):16-23.

Weare, K., and M. Nind. 2011. "Mental health promotion and problem prevention in schools: what does the evidence say?". Health Promotion International 26 Suppl 1:i29-69.

White, J., J. Hawkins, K. Madden, A. Grant, V. Er, L. Angel, T. Pickles, et al. 2017. Adapting the ASSIST model of informal peer-led intervention delivery to the Talk to FRANK drug prevention programme in UK secondary schools (ASSIST + FRANK): intervention development, refinement and a pilot cluster randomised controlled trial. Southampton (UK): NIHR Journals Library.

Whitton, Sarah W., and Brian A. Buzzella. 2012. "Using Relationship Education Programs with Same-Sex Couples: A Preliminary Evaluation of Program Utility and Needed Modifications." Marriage \& Family Review 48 (7):667-88. 
Table 1: Inclusion / exclusion criteria

\begin{tabular}{|c|c|c|}
\hline & Inclusion criteria & Exclusion criteria \\
\hline Population & $\begin{array}{l}\text { Age: } 11 \text { to } 18 \text { years old. Sub- } \\
\text { groups of children within this } \\
\text { age-group are eligible. The } \\
\text { programmes' targeted } \\
\text { population should include } \\
\text { young people }<18 \text { years old. } \\
\text { Lower age boundary needs to } \\
\text { include } 11 \text { and } 12 \text {. Upper age } \\
\text { boundary needs to include } 17 \\
\text { and } 18 \text {. }\end{array}$ & $\begin{array}{l}\text { Any programme that has not } \\
\text { been developed to be used in a } \\
\text { general population of young } \\
\text { people (<18 years) e.g. } \\
\text { autism/learning } \\
\text { disabilities/refugees. }\end{array}$ \\
\hline Programmes & $\begin{array}{l}\text { Generic and or skill-specific } \\
\text { intimate relationship skill } \\
\text { programmes used in the English } \\
\text { language, regardless of current } \\
\text { use; group and individual } \\
\text { programmes are eligible, } \\
\text { school-based programmes and } \\
\text { or programmes using another } \\
\text { setting/method for delivery. } \\
\text { Programmes aimed at one } \\
\text { gender are included. }\end{array}$ & $\begin{array}{l}\text { Any programme where the aim } \\
\text { does not refer specifically to } \\
\text { relationship skills for intimate } \\
\text { relationship (e.g. aim is to } \\
\text { prevent HIV or pregnancy). }\end{array}$ \\
\hline Study design & Any type of study design & \\
\hline Date & 1996 onwards & \\
\hline Language & English language & $\begin{array}{l}\text { Any programme for which an } \\
\text { English language version has not } \\
\text { been developed. }\end{array}$ \\
\hline
\end{tabular}




\begin{tabular}{|c|c|}
\hline 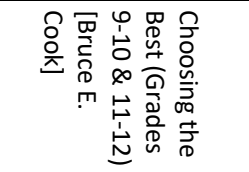 & 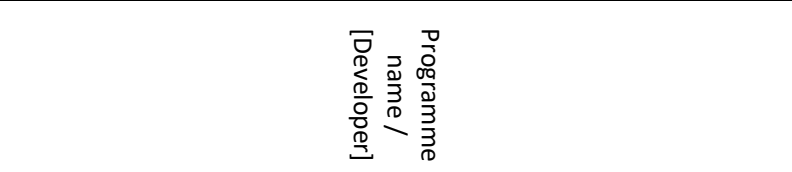 \\
\hline 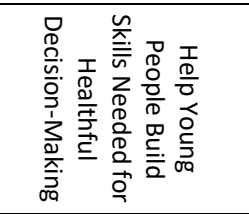 & 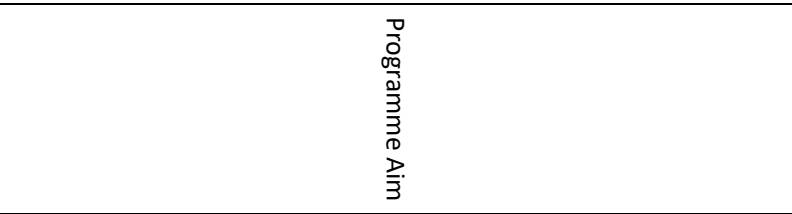 \\
\hline 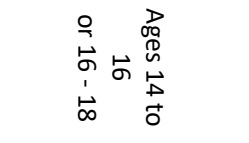 & 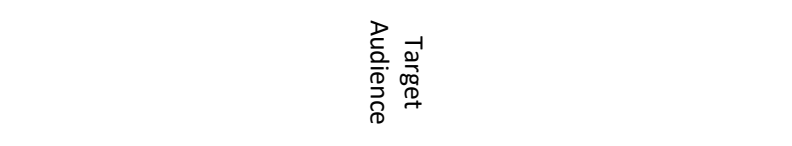 \\
\hline$\stackrel{\complement}{\triangle}$ & 을. \\
\hline 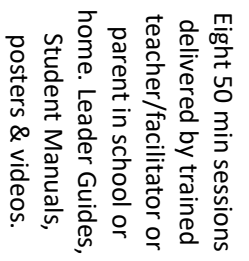 & 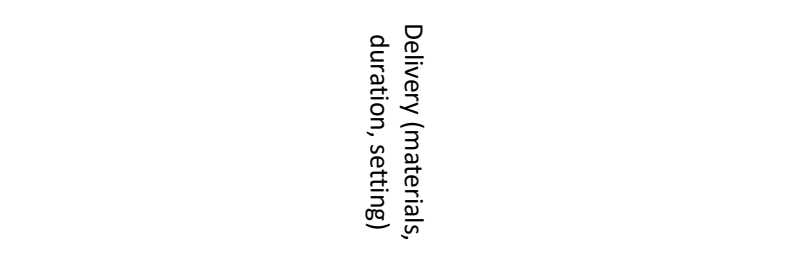 \\
\hline 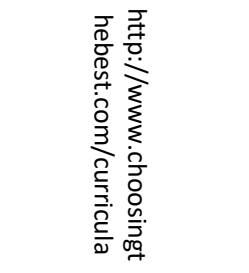 & 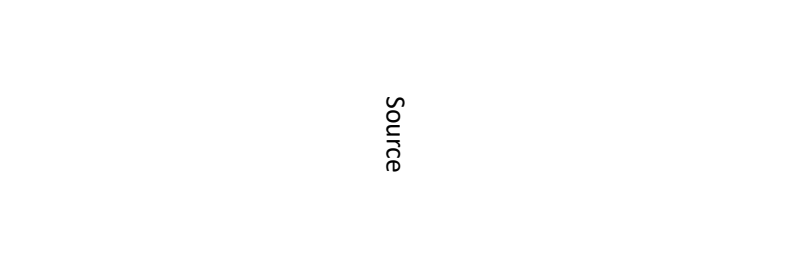 \\
\hline$\times$ & Commitment \\
\hline \multirow[t]{3}{*}{$\times$} & Communication \\
\hline & Conflict Reduction/Dealing with Differences in Personal Expectations \\
\hline & Conflict Resolution/Repairing Relationships after Conflict \\
\hline \multirow[t]{5}{*}{$\times$} & Critical Thinking/Decision Making \\
\hline & Empathy \\
\hline & Ending Relationships \\
\hline & Finance Management in a Relationship \\
\hline & Negotiation/Prioritising \\
\hline \multirow[t]{2}{*}{$\times$} & Partner Selection \\
\hline & Problem Solving/Crisis Management \\
\hline \multirow[t]{4}{*}{$\times$} & Recognising Healthy Relationship Patterns \\
\hline & Recognising Unhealthy Relationship Patterns \\
\hline & Resilience/Healthy Coping strategies/Self-regulation \\
\hline & Respect \\
\hline$\times$ & Self-Confidence/Assertiveness \\
\hline \multirow[t]{2}{*}{$\times$} & Setting Sexual Limits/Refusal Skills/Responsibility \\
\hline & Trust \\
\hline \multirow[t]{3}{*}{$\times$} & Understanding own Personal Values/Goal Setting \\
\hline & Understanding Sexuality \\
\hline & Understanding the Effects of Gender Stereotypes on Behaviour \\
\hline$\times$ & Understanding the Effects of the Media on Expectations \\
\hline
\end{tabular}




\begin{tabular}{|c|c|c|c|c|c|c|c|c|c|c|c|c|c|c|c|c|c|c|c|c|c|c|c|c|c|c|}
\hline $\begin{array}{l}\text { Connections: } \\
\text { Dating \& } \\
\text { Emotions } \\
\text { [Charlene R. } \\
\text { Kamper] }\end{array}$ & $\begin{array}{l}\text { Promote } \\
\text { Healthy } \\
\text { Relationship } \\
\text { Behaviours }\end{array}$ & Ages 11 - 17 & USA & $\begin{array}{l}\text { Fifteen } 60 \text { min sessions } \\
\text { delivered by trained } \\
\text { teacher/facilitator in } \\
\text { school. Guide book, } \\
\text { DVD, Student } \\
\text { Handbook, Activity } \\
\text { Cards, role-play, } \\
\text { discussion. }\end{array}$ & $\begin{array}{l}\text { (Sparks, Lee, and } \\
\text { Spjeldnes 2012) }\end{array}$ & $x$ & & & & $x$ & $x$ & & & & & $x$ & $x$ & & & & $x$ & $x$ & & & & \\
\hline $\begin{array}{l}\text { Connections: } \\
\text { Relationships } \\
\text { \& Marriage } \\
\text { [Charlene R. } \\
\text { Kamper] }\end{array}$ & $\begin{array}{c}\text { Improve } \\
\text { Understanding } \\
\text { of Premarital \& } \\
\text { Post marital } \\
\text { Relationships }\end{array}$ & Ages 16 - 21 & USA & $\begin{array}{l}\text { Eighteen } 60 \text { min } \\
\text { sessions delivered in } \\
\text { school by trained } \\
\text { teacher/facilitator. } \\
\text { Instructor manual, } \\
\text { student journals, } \\
\text { posters, roleplays \& } \\
\text { discussion. } \\
\end{array}$ & $\begin{array}{l}\text { https://www.dibbleins } \\
\text { titute.org/connections } \\
\text {-relationships- } \\
\text { marriage/ }\end{array}$ & $x$ & $x$ & $\mathrm{x}$ & $\mathrm{x}$ & & $x$ & $\mathrm{x}$ & $x$ & $\mathrm{x}$ & $x$ & $x$ & & & & & & $x$ & $\mathrm{x}$ & & & \\
\hline \begin{tabular}{l|} 
DO \\
[Collaboration \\
of UK \\
Organisations \\
with expertise \\
in RSE and \\
supported by \\
DUREX]
\end{tabular} & $\begin{array}{l}\text { Truly Inclusive } \\
\text { Relationships } \\
\text { and Sex } \\
\text { Education }\end{array}$ & Ages $14-16$ & UK & $\begin{array}{c}\text { Six } 1 \text { hour sessions } \\
\text { delivered by teacher in } \\
\text { school. Lesson plans, } \\
\text { activity materials, } \\
\text { PowerPoint slides \& flip } \\
\text { cards. Requires } \\
\text { standard classroom } \\
\text { materials. }\end{array}$ & $\begin{array}{l}\text { https://www.dosrefor } \\
\text { schools.com/) }\end{array}$ & $x$ & & & $\mathrm{x}$ & $x$ & $x$ & & $x$ & & & $x$ & $x$ & $\mathrm{x}$ & & $x$ & $x$ & & & $x$ & $x$ & $x$ \\
\hline \begin{tabular}{l|} 
Friend Flips \\
[a team of \\
educators of \\
Department of \\
Health and \\
Kinesiology, \\
Texas A\&M \\
University \\
\end{tabular} & $\begin{array}{l}\text { Teach Young } \\
\text { People to } \\
\text { Recognise } \\
\text { Characteristics } \\
\text { of Healthy \& } \\
\text { Unhealthy } \\
\text { Relationships }\end{array}$ & Ages 12 - 14 & USA & $\begin{array}{l}\text { One } 55 \text { min session } \\
\text { delivered by teacher in } \\
\text { school. Teacher guide, } \\
\text { fact sheets, activity flip } \\
\text { cards and student story } \\
\text { guide provided. }\end{array}$ & (Szucs et al. 2015) & & & & & & & & & $\mathrm{x}$ & & $x$ & $x$ & & & & & & $\mathrm{x}$ & & & \\
\hline $\begin{array}{l}\text { Growing } \\
\text { Respect } \\
\text { /LOVEBiTES } \\
\text { [National } \\
\text { Association for } \\
\text { Prevention of } \\
\text { Child abuse } \\
\text { and Neglect } \\
\text { (NAPCAN)] } \\
\end{array}$ & $\begin{array}{l}\text { Encourage } \\
\text { Respectful } \\
\text { Relationships }\end{array}$ & $\begin{array}{l}\text { Ages } 10-13 \\
\text { or } 15-16\end{array}$ & Australia & $\begin{array}{l}\text { Programmes range } \\
\text { from } 6 \text { to } 13 \text { weeks } \\
\text { delivered by trained } \\
\text { teacher in school. } \\
\text { Requires smartboard \& } \\
\text { classroom materials for } \\
\text { activities. }\end{array}$ & $\begin{array}{l}\text { (Walsh and Peters } \\
\text { 2011) }\end{array}$ & & & $x$ & $\mathrm{x}$ & & & & & & $x$ & & $x$ & & $x$ & & & & & & & \\
\hline
\end{tabular}




\begin{tabular}{|c|c|c|c|c|c|c|c|c|c|c|c|c|c|c|c|c|c|c|c|c|c|c|c|c|}
\hline $\begin{array}{l}\text { Healthy } \\
\text { Choices, } \\
\text { Healthy } \\
\text { Relationships } \\
\text { [Charlene R. } \\
\text { Kamper] }\end{array}$ & $\begin{array}{l}\text { Promote } \\
\text { Healthy } \\
\text { Relationship } \\
\text { Behaviours }\end{array}$ & Ages $13-18$ & USA & \begin{tabular}{|c|} 
Eleven 60 min sessions \\
delivered by trained \\
teacher/facilitator in \\
school. Includes \\
Instructor guide, lesson \\
plans, posters \& \\
student materials incl. \\
game \& 'bill of rights' \\
wallet cards. \\
\end{tabular} & $\begin{array}{l}\text { https://www.dibbleins } \\
\text { titute.org/healthy- } \\
\text { choices-healthy- } \\
\text { relationships }\end{array}$ & $x$ & & & $x$ & & & & & & & $x$ & $x$ & $x$ & & & $x$ & & & $x$ \\
\hline $\begin{array}{l}\text { I Like, Like You } \\
\text { [Relationships } \\
\text { Australia } \\
\text { Victoria (RAV)] }\end{array}$ & $\begin{array}{l}\text { Promote } \\
\text { Healthy } \\
\text { Relationship } \\
\text { Behaviours }\end{array}$ & Ages 14 - 16 & Australia & $\begin{array}{c}\text { Four to six sessions } \\
\text { delivered by teacher in } \\
\text { school. Lesson plans } \\
\text { and guidebook. } \\
\text { Requires standard } \\
\text { classroom materials. }\end{array}$ & $\begin{array}{l}\text { https://www.relations } \\
\text { hipsvictoria.com.au/se } \\
\text { rvices/childrens- } \\
\text { services/ILIYY }\end{array}$ & $x$ & $x$ & $x$ & & & $\mathrm{x}$ & & & & $x$ & $x$ & $x$ & & & & $x$ & & $x$ & $x$ \\
\hline \begin{tabular}{|l|} 
It's All One \\
Curriculum \\
[the \\
Population \\
Council in \\
collaboration \\
with six other \\
nongovernme \\
ntal \\
organizations]
\end{tabular} & $\begin{array}{l}\text { Provide a } \\
\text { Unified } \\
\text { Approach to } \\
\text { Sexuality, } \\
\text { Gender, HIV \& } \\
\text { Human Rights } \\
\text { Education }\end{array}$ & Ages 15+ & $\begin{array}{l}\text { International } \\
\text { Collaboration }\end{array}$ & $\begin{array}{l}\text { Eight } 1 \text { hour sessions } \\
\text { delivered by } \\
\text { teacher/youth worker } \\
\text { in school or community } \\
\text { setting. } \\
\text { Instructor/Facilitator } \\
\text { Guidebook. Lesson } \\
\text { plans, case studies \& } 54 \\
\text { classroom activities. }\end{array}$ & $\begin{array}{c}\text { (Haberland et al. } \\
2009 \text { ) }\end{array}$ & $\mathrm{x}$ & & & $x$ & $\mathrm{x}$ & & $x$ & & $\mathrm{x}$ & & & & $x$ & \begin{tabular}{c|c}
$x$ & $x$ \\
\end{tabular} & $x$ & $x$ & $\mathrm{x}$ & $x$ & $x$ \\
\hline $\begin{array}{l}\text { Love House } \\
\text { [Brigitte Cizek } \\
\text { and Helmuth } \\
\text { Schattovits] }\end{array}$ & $\begin{array}{l}\text { Encourage } \\
\text { Awareness of } \\
\text { Characteristics } \\
\text { of Healthy } \\
\text { Romantic } \\
\text { Relationship }\end{array}$ & Ages 13 - 18 & Austria & $\begin{array}{l}\text { Delivered by teachers } \\
\text { for variety of } \\
\text { educational settings } \\
\text { e.g. high school or } \\
\text { family relations class. } \\
\text { Teacher guide provided. } \\
\text { Requires standard } \\
\text { classsoom materials. } \\
\text { Duration undefined } \\
\end{array}$ & $\begin{array}{l}\text { (Miller and Cizek } \\
\text { 2006) }\end{array}$ & & & & & & & & $x$ & & & & & & & & $x$ & & & \\
\hline
\end{tabular}




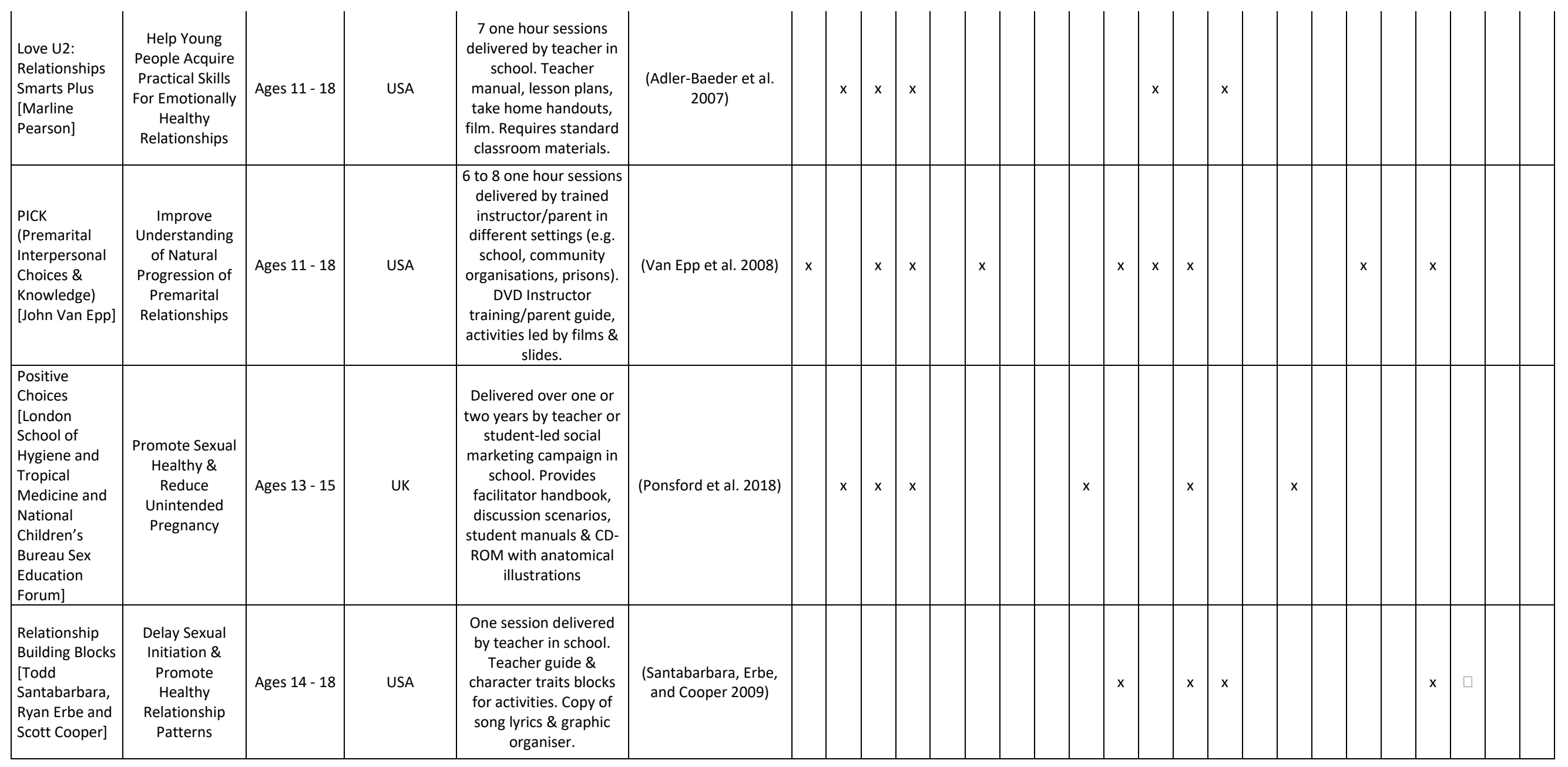




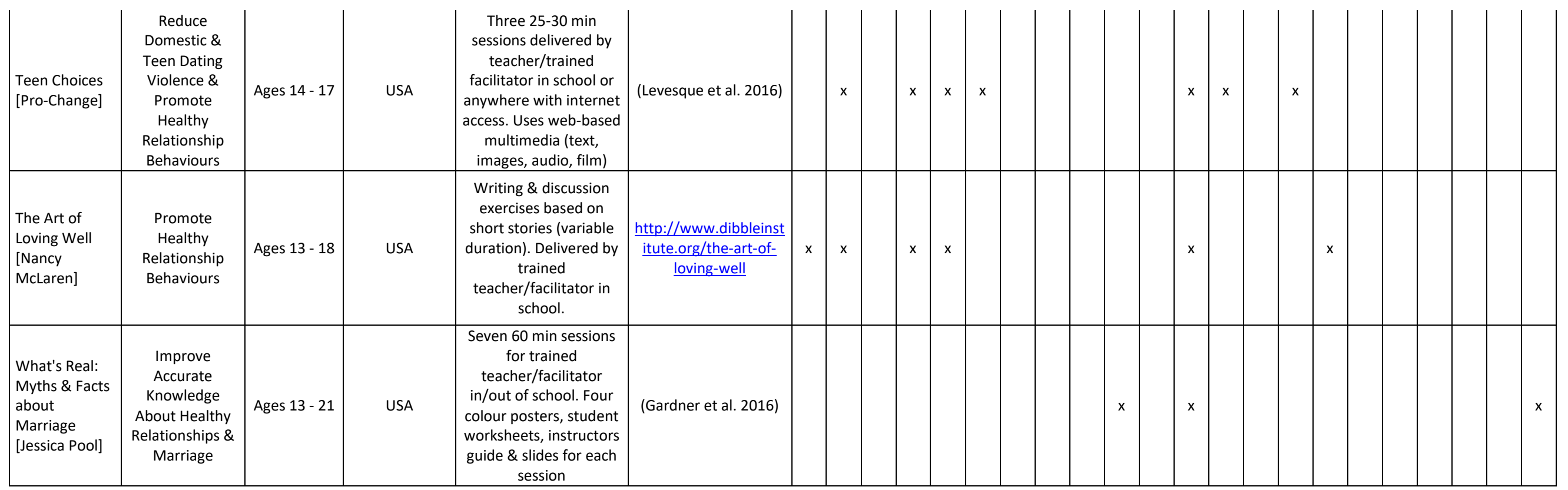


Figure 1: PRISMA Flow Diagram, based on Moher, Liberati, Tetzlaff, and Altman, 2009

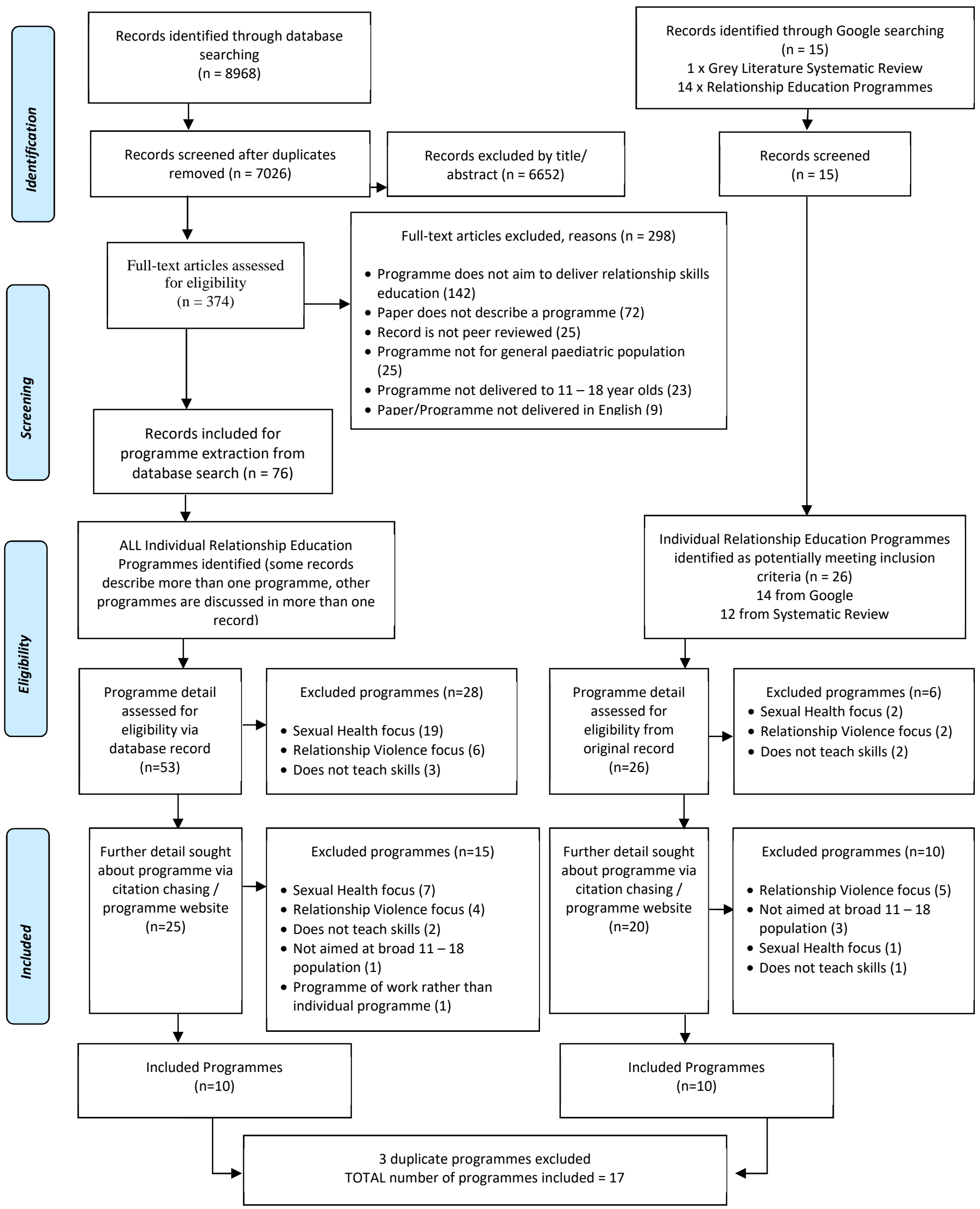

*It was decided not to pursue these papers as the programmes they each referred to in their abstracts were discussed in other included records. 
Supplementary Table 3: Search string as used for OVID MEDLINE

\begin{tabular}{|c|c|c|}
\hline Database & $\begin{array}{l}\text { Ovid MEDLINE@ Epub Ahead of Print, In-Process \& Other } \\
\text { Non-Indexed Citations and Ovid MEDLINE® without Revisions } \\
1996 \text { to daily update }\end{array}$ & \\
\hline $\begin{array}{l}\text { Date } \\
\text { Search } \\
\text { Run }\end{array}$ & 8th March 2017 (incl related terms) & \\
\hline $\begin{array}{l}\text { Search } \\
\text { line }\end{array}$ & Search term & Results \\
\hline$\# 1$ & Adolescent/ & 243970 \\
\hline$\# 2$ & Young Adult/ & 273791 \\
\hline$\# 3$ & adolescen*.ti,ab & 69148 \\
\hline$\# 4$ & young adult*.ti,ab & 23687 \\
\hline$\# 5$ & ((student*or pupil*) adj3 school).ti,ab. & 0 \\
\hline$\# 6$ & Youth.ti,ab & 19123 \\
\hline$\# 7$ & teen*.ti,ab & \\
\hline$\# 8$ & Juvenile.ti,ab & 14404 \\
\hline$\# 9$ & young people.ti,ab & 6791 \\
\hline$\# 10$ & girlfriend.ti,ab & 78 \\
\hline$\# 11$ & boyfriend.ti,ab & 96 \\
\hline$\# 12$ & high schools.ti,ab & 1455 \\
\hline$\# 13$ & high school education.ti,ab & 692 \\
\hline$\# 14$ & secondary education.ti,ab & 677 \\
\hline$\# 15$ & ((secondary or high) adj school*).ti,ab & 10786 \\
\hline$\# 16$ & Schools/ & 6319 \\
\hline$\# 17$ & $\begin{array}{l}1 \text { or } 2 \text { or } 3 \text { or } 4 \text { or } 5 \text { or } 6 \text { or } 7 \text { or } 8 \text { or } 9 \text { or } 10 \text { or } 11 \text { or } 12 \text { or } 13 \text { or } 14 \text { or } \\
15 \text { or } 16\end{array}$ & 441080 \\
\hline
\end{tabular}

\begin{tabular}{|l|l|l|}
\hline$\# 18$ & interpersonal relations/ & 9957 \\
\hline$\# 19$ & courtship/ & 428 \\
\hline$\# 20$ & love/ & 387 \\
\hline$\# 21$ & marriage/ & 1450 \\
\hline
\end{tabular}




\begin{tabular}{|c|c|c|}
\hline$\# 22$ & (relationship* adj skill).ti,ab & 55 \\
\hline \#23 & ((romantic or intimate or sexual) adj partner*).ti,ab & 6160 \\
\hline$\# 24$ & ((romantic or intimate or sexual) adj couple*).ti,ab & 49 \\
\hline$\# 25$ & ((romantic or intimate or sexual) adj relationship*).ti,ab & 2157 \\
\hline \#26 & Sex Education/ & 505 \\
\hline \#27 & ((Sex* or relationship*) adj3 education).ti,ab & 3963 \\
\hline \#28 & PSHE.ti,ab & 9 \\
\hline \#29 & Personal social health education.ti,ab & 0 \\
\hline \#30 & interpersonal attraction.ti, $\mathrm{ab}$ & 24 \\
\hline \#31 & interpersonal compatibility.ti,ab & 1 \\
\hline \#32 & sexual attitudes.ti,ab & 200 \\
\hline \#33 & social dating.ti,ab & 1 \\
\hline \#34 & romance.ti,ab & 143 \\
\hline$\# 35$ & intimacy.ti,ab & 1003 \\
\hline \#36 & cohabitation.ti,ab & 584 \\
\hline$\# 37$ & $\begin{array}{l}18 \text { or } 19 \text { or } 20 \text { or } 21 \text { or } 22 \text { or } 23 \text { or } 24 \text { or } 25 \text { or } 26 \text { or } 27 \text { or } 28 \text { or } 29 \text { or } \\
30 \text { or } 31 \text { or } 32 \text { or } 33 \text { or } 34 \text { or } 35 \text { or } 36\end{array}$ & 23952 \\
\hline
\end{tabular}

\begin{tabular}{|c|c|c|}
\hline$\# 38$ & Teaching/ & 4511 \\
\hline$\# 39$ & Program Development/ & 4121 \\
\hline$\# 40$ & Program Evaulation/ & 9976 \\
\hline$\# 41$ & Curriculum/ & 8968 \\
\hline$\# 42$ & School health services/ & 1919 \\
\hline$\# 43$ & social skills/ & 600 \\
\hline$\# 44$ & Guidance.ti,ab & 31224 \\
\hline$\# 45$ & Training.ti,ab & 101686 \\
\hline$\# 46$ & $\begin{array}{l}((\text { online or web-based or school* or teach* or education*) adj } 2 \\
\left(\text { model* }^{*} \text { or method* or material* or plan* or resource* or }\right. \\
\text { intervention*)).ti,ab }\end{array}$ & 19336 \\
\hline \#47 & $\begin{array}{l}\text { ((curriculum or syllabus or program) adj2 (develop* or evaluat* or } \\
\text { instruct* or educat*)).ti,ab }\end{array}$ & 11271 \\
\hline
\end{tabular}




\begin{tabular}{|l|l|l|}
\hline$\# 48$ & lesson plan.ti,ab & 23 \\
\hline$\# 49$ & $\begin{array}{l}\text { (course adj }(\text { content or evaluat* or develop* or aim* or } \\
\text { objective*) } . t i, a b\end{array}$ & 758 \\
\hline$\# 50$ & education program planning.ti,ab & 7 \\
\hline$\# 51$ & programmed instruction.ti,ab & 10 \\
\hline$\# 52$ & school-based intervention.ti,ab & 282 \\
\hline$\# 54$ & course evaluation.ti,ab & 139 \\
\hline$\# 55$ & $\begin{array}{l}38 \text { or } 39 \text { or } 40 \text { or } 41 \text { or } 42 \text { or } 43 \text { or } 45 \text { or } 46 \text { or } 47 \text { or } 48 \text { or } 49 \text { or } 50 \text { or } \\
51 \text { or } 52 \text { or } 53 \text { or } 54\end{array}$ & 171960 \\
\hline
\end{tabular}


Supplementary Table 2: Excluded Programmes with Reason for Exclusion

\begin{tabular}{|c|c|c|c|c|c|}
\hline Programme Name & $\begin{array}{c}\text { Target } \\
\text { Audienc } \\
\text { e } \\
\end{array}$ & Programme Aim & $\begin{array}{l}\text { Country of } \\
\text { Origin }\end{array}$ & Source & Reason for Exclusion \\
\hline $\begin{array}{l}\text { A PAUSE programme-Adding Power } \\
\text { And Understanding in Sex Education }\end{array}$ & $\begin{array}{c}\text { Ages } 13- \\
14\end{array}$ & Sex Education & UK & $\begin{array}{l}\text { (Mellanby et al. 1995; } \\
\text { Mellanby, Phelps, and Tripp } \\
\text { 1996) }\end{array}$ & Sexual Health focus \\
\hline About Us & $\begin{array}{c}\text { Not } \\
\text { specified }\end{array}$ & $\begin{array}{l}\text { Promote healthy relationship } \\
\text { behaviours \& increase } \\
\text { contraceptive use }\end{array}$ & USA & $\begin{array}{c}\text { (Coyle, Anderson, and } \\
\text { Administration for Children and } \\
\text { Families 2018) }\end{array}$ & Sexual Health focus \\
\hline Best Friends & $\begin{array}{l}\text { Ages } 11- \\
\quad 18\end{array}$ & Character Education & USA & (Best Friends Foundation 2018) & $\begin{array}{l}\text { Does not teach } \\
\text { relationship skills }\end{array}$ \\
\hline Chesterfield Relate & $\begin{array}{l}\text { Ages } 14- \\
\quad 18\end{array}$ & Reduce Domestic Violence & USA & $\begin{array}{l}\text { (McLeod, Jones, and Cramer } \\
\text { 2015) }\end{array}$ & $\begin{array}{l}\text { Relationship Violence } \\
\text { focus }\end{array}$ \\
\hline $\begin{array}{l}\text { Choosing, Noticing, Responding, Ending } \\
\text { and Bouncing Back }\end{array}$ & $\begin{array}{l}\text { Ages } 13- \\
16 \\
\text { Female } \\
\text { only }\end{array}$ & $\begin{array}{l}\text { Reduce Chronic Partner } \\
\text { Violence }\end{array}$ & Australia & (Murphy 2011) & $\begin{array}{l}\text { Relationship Violence } \\
\text { focus }\end{array}$ \\
\hline Dating and Sexual Responsibility & $\begin{array}{c}\text { Ages } 15- \\
16\end{array}$ & $\begin{array}{c}\text { Prevent Coercive Sexual } \\
\text { Behaviour }\end{array}$ & USA & $\begin{array}{l}\text { (Pacifici, Stoolmiller, and } \\
\text { Nelson 2001) }\end{array}$ & $\begin{array}{l}\text { Relationship Violence } \\
\text { focus }\end{array}$ \\
\hline
\end{tabular}




\begin{tabular}{|c|c|c|c|c|c|}
\hline Dating Matters & $\begin{array}{l}\text { Ages } 13- \\
15\end{array}$ & Reduce domestic violence & USA & $\begin{array}{c}\text { (Tharp et al. 2011; Centers for } \\
\text { Disease Control and Prevention } \\
\text { n.d.) }\end{array}$ & $\begin{array}{l}\text { Relationship Violence } \\
\text { focus }\end{array}$ \\
\hline Expect Respect & $\begin{array}{c}\text { Ages } 13- \\
18\end{array}$ & $\begin{array}{c}\text { Promote healthy relationship } \\
\text { behaviours }\end{array}$ & UK & (Women's Aid 2015) & $\begin{array}{l}\text { Relationship Violence } \\
\text { focus }\end{array}$ \\
\hline Expressive and group technique & $\begin{array}{c}\text { Ages } 14- \\
18 \\
\text { Children } \\
\text { of } \\
\text { Divorce } \\
\text { only } \\
\end{array}$ & $\begin{array}{l}\text { Promote healthy relationship } \\
\text { behaviours }\end{array}$ & USA & (Whitten and Burt 2015) & $\begin{array}{l}\text { Does not teach } \\
\text { relationship skills }\end{array}$ \\
\hline Fourth R: Skills for Youth Relationships & $\begin{array}{l}\text { Ages } 14- \\
15\end{array}$ & $\begin{array}{l}\text { Reduce adolescent dating } \\
\text { violence }\end{array}$ & Canada & (Wolfe et al. 2009) & $\begin{array}{l}\text { Relationship Violence } \\
\text { focus }\end{array}$ \\
\hline $\begin{array}{l}\text { FreeUp (Living Respectfully) [Renamed: } \\
\text { Respect100] }\end{array}$ & $\begin{array}{l}\text { Ages } 11- \\
19 \text { Male } \\
\text { only }\end{array}$ & $\begin{array}{l}\text { Promote critical analysis of } \\
\text { gender stereotypes \& reduce } \\
\text { domestic violence }\end{array}$ & UK & (A call to men UK 2019) & $\begin{array}{l}\text { Relationship Violence } \\
\text { focus }\end{array}$ \\
\hline Girl Time & $\begin{array}{c}\text { Ages } 12 \text { - } \\
14 \\
\text { Female } \\
\text { only }\end{array}$ & $\begin{array}{l}\text { Encourage safer sexual } \\
\text { practices }\end{array}$ & Canada & (Brunk et al. 2008) & Sexual Health focus \\
\hline Health Education for Youth (hey) & $\begin{array}{c}\text { Ages } 13- \\
17\end{array}$ & Sex Education & USA & (Stevens et al. 2013) & Sexual Health focus \\
\hline It's Your Game (IYG) -Tech & $\begin{array}{c}\text { Ages } 13- \\
14\end{array}$ & $\begin{array}{l}\text { Reduce HIV/STI and } \\
\text { pregnancy }\end{array}$ & USA & (Peskin et al. 2015) & Sexual Health focus \\
\hline
\end{tabular}




\begin{tabular}{|c|c|c|c|c|c|}
\hline Katie Brown Educational Program & $\begin{array}{l}\text { Ages } 10- \\
18\end{array}$ & Reduce dating violence & USA & (Joppa et al. 2016) & $\begin{array}{l}\text { Relationship Violence } \\
\text { focus }\end{array}$ \\
\hline Life Planning education & $\begin{array}{c}\text { Ages } 12- \\
18\end{array}$ & $\begin{array}{l}\text { Prepare for work and promote } \\
\text { healthy relationship } \\
\text { behaviours }\end{array}$ & USA & (Advocates for Youth 1995) & $\begin{array}{l}\text { Does not teach } \\
\text { relationship skills }\end{array}$ \\
\hline $\begin{array}{l}\text { Life Skills and HIV/AIDS Education: } \\
\text { Learning Program for Grades 8-12 }\end{array}$ & $\begin{array}{c}\text { Ages } 12- \\
18\end{array}$ & $\begin{array}{l}\text { Reduce \& promote coping } \\
\text { strategies for HIV/AIDS }\end{array}$ & South Africa & (Magnani et al. 2005) & Sexual Health focus \\
\hline love is respect & $\begin{array}{c}\text { Ages } 14 \text { - } \\
18\end{array}$ & Reduce domestic violence & USA & (Love is respect dot org 2017) & $\begin{array}{l}\text { Relationship Violence } \\
\text { focus }\end{array}$ \\
\hline loves-me-not & $\begin{array}{l}\text { Ages } 16- \\
\quad 18\end{array}$ & $\begin{array}{l}\text { Promote healthy relationship } \\
\text { behaviours }\end{array}$ & New Zealand & (New Zealand Police 2018) & $\begin{array}{l}\text { Relationship Violence } \\
\text { focus }\end{array}$ \\
\hline Love Notes v2.1 & $\begin{array}{c}\text { Ages } 15- \\
24 \mathrm{At} \\
\text { risk of } \\
\text { pregnanc } \\
\mathrm{y} \\
\end{array}$ & $\begin{array}{l}\text { Help Young People make } \\
\text { wise relationship \& sexual } \\
\text { choices }\end{array}$ & USA & (Scott et al. 2012) & $\begin{array}{l}\text { Not aimed at broad } 11 \text { - } \\
18 \text { population }\end{array}$ \\
\hline Making Smart Choices (MSC) & $\begin{array}{c}\text { Ages } 12- \\
16\end{array}$ & Sex Education & Hong Kong & (Alvin et al. 2015) & Sexual Health focus \\
\hline matesanddates & $\begin{array}{c}\text { Ages } 13- \\
17\end{array}$ & Reduce domestic violence & New Zealand & $\begin{array}{l}\text { (Accident Compensation } \\
\text { Corporation n.d.) }\end{array}$ & $\begin{array}{l}\text { Relationship Violence } \\
\text { focus }\end{array}$ \\
\hline
\end{tabular}




\begin{tabular}{|c|c|c|c|c|c|}
\hline Media Aware Relationships & Ages $18+$ & $\begin{array}{c}\text { Promote critical analysis of } \\
\text { media messages about sexual } \\
\text { behaviour }\end{array}$ & USA & $\begin{array}{l}\text { (Scull, Malik, and Kupersmidt } \\
\text { 2014) }\end{array}$ & $\begin{array}{l}\text { Not aimed at broad } 11- \\
18 \text { population }\end{array}$ \\
\hline Media Relate Project & $\begin{array}{l}\text { Ages } 12- \\
15\end{array}$ & $\begin{array}{c}\text { Promote critical analysis of } \\
\text { media messages about sexual } \\
\text { behaviour }\end{array}$ & UK & (Bragg 2006) & $\begin{array}{l}\text { Does not teach } \\
\text { relationship skills }\end{array}$ \\
\hline Mpondombili & $\begin{array}{c}\text { Ages } 14- \\
17\end{array}$ & $\begin{array}{l}\text { Reduce HIV/AIDS and } \\
\text { unintended pregnancy }\end{array}$ & South Africa & (Mantell et al. 2006) & Sexual Health focus \\
\hline Pono Choices Curriculum & $\begin{array}{c}\text { Ages } 11- \\
14 \\
\text { Hawaiian } \\
\text { populatio } \\
\text { n only } \\
\end{array}$ & Sex Education & USA & $\begin{array}{l}\text { (Manaseri, Uehara, and Roberts } \\
\text { 2014) }\end{array}$ & Sexual Health focus \\
\hline Positive Prevention Plus & $\begin{array}{c}\text { Ages } 14- \\
18\end{array}$ & $\begin{array}{l}\text { Reduce HIV/STI and } \\
\text { pregnancy }\end{array}$ & USA & $\begin{array}{l}\text { (LaChausse, Clark, and Chapple } \\
\text { 2014) }\end{array}$ & Sexual Health focus \\
\hline PREPARE & $\begin{array}{c}\text { Ages } 12- \\
14\end{array}$ & $\begin{array}{l}\text { Reduce HIV and domestic } \\
\text { violence }\end{array}$ & South Africa & (Mathews et al. 2015) & Sexual Health focus \\
\hline Queer Sex Ed & $\begin{array}{l}\text { Ages } 16- \\
20 \text { LGBT } \\
\text { only }\end{array}$ & Sex Education & USA & (Mustanski et al. 2015) & Sexual Health focus \\
\hline Reducing the risk & $\begin{array}{c}\text { Ages } 14- \\
19\end{array}$ & $\begin{array}{l}\text { Delay sexual initiation and } \\
\text { promote safe sex practices }\end{array}$ & USA & (Kelsey and Layzer 2014) & Sexual Health focus \\
\hline
\end{tabular}




\begin{tabular}{|c|c|c|c|c|c|}
\hline $\begin{array}{l}\text { RELATE (Relationship Education Leading } \\
\text { Adolescents Towards Empowerment) }\end{array}$ & $\begin{array}{c}\text { Not } \\
\text { specified }\end{array}$ & Reduce Domestic Violence & USA & $\begin{array}{l}\text { (McLeod, Jones, and Cramer } \\
\text { 2015) }\end{array}$ & $\begin{array}{l}\text { Relationship Violence } \\
\text { focus }\end{array}$ \\
\hline $\begin{array}{l}\text { Relationship Intelligence } \\
\text { (Lovesmart/freeteens/Teen Smart About } \\
\text { Sex) }\end{array}$ & $\begin{array}{l}\text { Ages } 11- \\
18\end{array}$ & $\begin{array}{l}\text { Promote healthy relationship } \\
\text { behaviours }\end{array}$ & USA & (NJ Wise2Wait 2019) & $\begin{array}{l}\text { Does not teach } \\
\text { relationship skills }\end{array}$ \\
\hline Responsible Sexuality Program & $\begin{array}{c}\text { Ages } 14- \\
18\end{array}$ & Sex Education & USA & (Kassirer and Griffiths 1997) & Sexual Health focus \\
\hline Safe Dates & $\begin{array}{c}\text { Ages } 13- \\
15\end{array}$ & Reduce domestic violence & USA & $\begin{array}{l}\text { (Jouriles, Platt, and McDonald } \\
\text { 2009) }\end{array}$ & $\begin{array}{l}\text { Relationship Violence } \\
\text { focus }\end{array}$ \\
\hline $\begin{array}{l}\text { School Health Center Healthy Adolescent } \\
\text { Relationships Program (SHARP) }\end{array}$ & $\begin{array}{l}\text { Ages } 14- \\
18\end{array}$ & Reduce domestic violence & USA & (Miller, Goldstein, et al. 2015) & $\begin{array}{l}\text { Relationship Violence } \\
\text { focus }\end{array}$ \\
\hline Sex Can Wait & $\begin{array}{l}\text { Ages } 10- \\
12\end{array}$ & Delay sexual initiation & USA & $\begin{array}{l}\text { (Spear, Young, and Denny } \\
\text { 1997) }\end{array}$ & $\begin{array}{l}\text { Does not teach } \\
\text { relationship skills }\end{array}$ \\
\hline $\begin{array}{l}\text { Sexual health and relationships education } \\
\text { (SHARE)/ The SHARE intervention }\end{array}$ & $\begin{array}{l}\text { Ages } 13- \\
15\end{array}$ & $\begin{array}{l}\text { Reduce unwanted pregnancy } \\
\text { and promote safe sexual } \\
\text { practices }\end{array}$ & Scotland & (Wight and Dixon 2004) & Sexual Health focus \\
\hline Sexual health education program & $\begin{array}{l}\text { Ages } 14- \\
15\end{array}$ & $\begin{array}{l}\text { Reduce HIV/STI, pregnancy } \\
\& \text { promote healthy } \\
\text { relationship behaviours }\end{array}$ & Canada & $\begin{array}{l}\text { (Smylie, Maticka-Tyndale, and } \\
\text { Boyd 2008) }\end{array}$ & Sexual Health focus \\
\hline
\end{tabular}




\begin{tabular}{|c|c|c|c|c|c|}
\hline Sexunzipped & $\begin{array}{c}\text { Ages } 16- \\
20\end{array}$ & Sex Education & UK & (McCarthy et al. 2012) & Sexual Health focus \\
\hline $\begin{array}{l}\text { Start Strong: Building Healthy Teen } \\
\text { Relationships/Teen dating violence } \\
\text { prevention program }\end{array}$ & $\begin{array}{l}\text { Ages } 11- \\
14\end{array}$ & $\begin{array}{l}\text { Reduce domestic violence \& } \\
\text { promote healthy relationship } \\
\text { behaviours }\end{array}$ & USA & (Miller, Williams, et al. 2015) & $\begin{array}{l}\text { Programme of work not } \\
\text { individual program }\end{array}$ \\
\hline Teen Outreach Program & $\begin{array}{c}\text { Ages } 14- \\
18\end{array}$ & $\begin{array}{l}\text { Improve adolescent's } \\
\text { aspirations and reduce teen } \\
\text { pregnancy }\end{array}$ & USA & $\begin{array}{l}\text { (Schmidt, Wandersman, and } \\
\text { Hills 2015) }\end{array}$ & Sexual Health focus \\
\hline TeensTalkHealth & $\begin{array}{l}\text { Ages } 14- \\
18\end{array}$ & $\begin{array}{c}\text { Encourage safer sexual } \\
\text { practices }\end{array}$ & USA & (Brady et al. 2015) & Sexual Health focus \\
\hline Tender's Healthy Relationships Project & $\begin{array}{c}\text { Ages } 13- \\
18\end{array}$ & $\begin{array}{l}\text { Promote healthy relationship } \\
\text { behaviours }\end{array}$ & UK & (Tender n.d.) & $\begin{array}{l}\text { Relationship Violence } \\
\text { focus }\end{array}$ \\
\hline The 2 HYPE Abstinence Club & $\begin{array}{c}\text { Ages } 12- \\
18\end{array}$ & $\begin{array}{l}\text { Reduce premarital sexual } \\
\text { activity and underage } \\
\text { pregnancy }\end{array}$ & USA & (Akintobi et al. 2011) & Sexual Health focus \\
\hline The 5 Love Languages & Ages 18+ & $\begin{array}{l}\text { Improve communication of } \\
\text { affection }\end{array}$ & USA & (The 5 Love Languages ${ }^{\circledR}$ n.d.) & $\begin{array}{l}\text { Not aimed at broad } 11- \\
18 \text { population }\end{array}$ \\
\hline The Candy Game exercise & $\begin{array}{c}\text { Ages } 13- \\
17\end{array}$ & $\begin{array}{l}\text { Improve understanding of } \\
\text { sexuality }\end{array}$ & USA & (Ott 2016) & $\begin{array}{l}\text { Does not teach } \\
\text { relationship skills }\end{array}$ \\
\hline
\end{tabular}




\begin{tabular}{|c|c|c|c|c|c|}
\hline The Human Development Programme & $\begin{array}{c}\text { Ages } 12 \text { - } \\
14\end{array}$ & Sex Education & Turkey & (Cok and Gray 2007) & Sexual Health focus \\
\hline $\begin{array}{l}\text { The Peer Led Sex Education Intervention } \\
\text { (RIPPLE) }\end{array}$ & $\begin{array}{c}\text { Ages } 13- \\
14\end{array}$ & Sex Education & UK & (Stephenson et al. 2004) & Sexual Health focus \\
\hline The Safe Relationships program & $\begin{array}{l}\text { Ages } 14- \\
18\end{array}$ & $\begin{array}{l}\text { Reduce domestic violence, } \\
\text { sexual abuse and teen } \\
\text { pregnancy }\end{array}$ & USA & (Lowe, Jones, and Banks 2007) & $\begin{array}{l}\text { Relationship Violence } \\
\text { focus }\end{array}$ \\
\hline The Sexuality Education Initiative (SEI) & $\begin{array}{l}\text { Ages } 14- \\
15\end{array}$ & $\begin{array}{c}\text { Reduce HIV/STI and } \\
\text { pregnancy and promote safe } \\
\text { sexual practices }\end{array}$ & USA & (Marques and Ressa 2013) & Sexual Health focus \\
\hline The World Starts with Me & $\begin{array}{l}\text { Ages } 12- \\
19\end{array}$ & Sex Education & Uganda & (Rijsdijk et al. 2011) & Sexual Health focus \\
\hline The Youth Relationships Project (YRP) & $\begin{array}{l}\text { Ages } 14- \\
17\end{array}$ & Reduce domestic violence & USA & $\begin{array}{l}\text { (Jouriles, Platt, and McDonald } \\
\text { 2009) }\end{array}$ & $\begin{array}{l}\text { Relationship Violence } \\
\text { focus }\end{array}$ \\
\hline True Love Waits & $\begin{array}{c}\text { Not } \\
\text { specified }\end{array}$ & $\begin{array}{l}\text { Abstinance pledge education } \\
\text { programme }\end{array}$ & USA & (Silliman 2003) & $\begin{array}{l}\text { Does not teach } \\
\text { relationship skills }\end{array}$ \\
\hline Ur Choice & $\begin{array}{c}\text { Ages } 14- \\
16\end{array}$ & Sex Education & UK & (McIver 2010) & Sexual Health focus \\
\hline
\end{tabular}




\begin{tabular}{|l|c|c|c|c|c|} 
WAIT (Why Am I Tempted?) Training & $\begin{array}{c}\text { Ages } 11- \\
18\end{array}$ & Sex and Pregnancy Prevention & USA & (Scott et al. 2012) & Sexual Health focus \\
\hline Wise Guys & $\begin{array}{c}\text { Ages } 11- \\
17 \text { Male } \\
\text { only }\end{array}$ & $\begin{array}{c}\text { Promote male responsibility } \\
\text { and reduce teen pregnancy }\end{array}$ & USA & $\begin{array}{c}\text { (Herrman, Moore, and Rahmer } \\
\text { 2016) }\end{array}$ & Sexual Health focus \\
\hline Within My Reach & Ages 18+ & $\begin{array}{c}\text { Promote healthy relationship } \\
\text { behaviours }\end{array}$ & USA & (Scott et al. 2012) & $\begin{array}{c}\text { Not aimed at broad 11 - } \\
18 \text { population }\end{array}$ \\
\hline $\begin{array}{l}\text { Would you Rather (WYR), with a Sexual } \\
\text { Health Twist! }\end{array}$ & $\begin{array}{c}\text { Ages } 14- \\
18\end{array}$ & $\begin{array}{c}\text { Encourage safer sexual } \\
\text { practices }\end{array}$ & USA & $\begin{array}{c}\text { (Rosen, McNeill, and Wilson } \\
\text { 2014) }\end{array}$ & Sexual Health focus \\
\hline You-Me-US & $\begin{array}{c}\text { Not } \\
\text { specified }\end{array}$ & $\begin{array}{c}\text { Reduce sexual risk taking } \\
\text { behaviours }\end{array}$ & USA & (Scott et al. 2012) & Sexual Health focus \\
\hline
\end{tabular}


References

A call to men UK. "A Call To Men UK - Youth Development: Respect100

Programme." Accessed 10 August 2019. http://www.acalltomen.org/youthdevelopment.

Accident Compensation Corporation. "Mates\&Dates." Accessed 8 August 2019. https://www.matesanddates.co.nz/.

Advocates for Youth. "Life planning education. A youth development program." Accessed 8 August 2019. https://www.advocatesforyouth.org/wpcontent/uploads/storage//advfy/documents/lpe.pdf.

Akintobi, T. H., J. C. Trotter, D. Evans, T. Johnson, N. Laster, D. Jacobs, and T. King. 2011. "Applications in bridging the gap: a community-campus partnership to address sexual health disparities among African-American youth in the south." Journal of Community Health 36 (3):486-94. doi: 10.1007/s10900-010-9332-8.

Alvin, C. M. Kwan, K. W. Chu Samuel, W. L. Hong Athena, Tam Frankie, M. Y. Lee Grace, and Mellecker Robin. 2015. "Making Smart Choices: A Serious Game for Sex Education for Young Adolescents." International Journal of GameBased Learning 5 (1):18-30. doi: 10.4018/ijgbl.2015010102.

Best Friends Foundation. "Best Friends." Accessed 10 August 2018. http://bestfriendsfoundation.org/what-is-best-friends/.

Brady, S. S., R. E. Sieving, L. G. Terveen, B. R. Rosser, A. J. Kodet, and V. D. Rothberg. 2015. "An Interactive Website to Reduce Sexual Risk Behavior: Process Evaluation of TeensTalkHealth." JMIR Research Protocols 4 (3):e106. doi: $10.2196 /$ resprot.3440.

Bragg, Sara. 2006. "'Having a real debate': using media as a resource in sex education." Sex Education 6 (4):317-31. doi: DOI: 10.1080/14681810600981830.

Brunk, Tammie, Sue Morris, B J Rye, Glenn J Meaney, Jennifer Yessis, Lisa Wenger, and Alexander McKay. 2008. "Girl Time: Development and implementation of a healthy sexuality program for girls Grades 7 and 8." Canadian Journal of Human Sexuality 2008 (17):1/2.

Centers for Disease Control and Prevention. "Dating Matters®: Strategies to Promote Healthy Teen Relationships." Accessed 10 August 2018. https://www.cdc.gov/violenceprevention/datingmatters/index.html. 
Cok, Figen, and Lizbeth Ann Gray. 2007. "Development of a sex education programme for 12-year-old to 14-year-old Turkish adolescents." Sex Education 7 (2):12741. doi: 10.1080/14681810701264466.

Coyle, Karin, Pamela Anderson, and Family \& Youth Services Bureau Administration for Children and Families. "About Us: A Healthy Relationships Program for Vulnerable Youth." Accessed 10 August 2018. https://www.etr.org/aboutus/our-projects/about-us-a-healthy-relationships-program-for-vulnerable-youth/.

Herrman, J. W., C. Moore, and B. Rahmer. 2016. "Focus on Teen Men: Evaluating the Effectiveness of the Wise Guys Program." Journal of Child and Adolescent Psychiatric Nursing 29 (1):37-43. doi: 10.1111/jcap.12133.

Joppa, M. C., C. J. Rizzo, A. V. Nieves, and L. K. Brown. 2016. "Pilot Investigation of the Katie Brown Educational Program: A School-Community Partnership." The Journal of School Health 86 (4):288-97. doi: 10.1111/josh.12378.

Jouriles, Ernest N, Cora Platt, and Renee McDonald. 2009. "Violence in Adolescent Dating Relationships." Prevention Researcher 16 (1):3-7.

Kassirer, A., and J. Griffiths. 1997. "The effectiveness of "The Responsible Sex Program": A brief high school sexual education intervention." Journal of Sex Education and Therapy 22 (2):5-11.

Kelsey, M., and J. Layzer. 2014. "Implementing three evidence-based program models: early lessons from the Teen Pregnancy Prevention Replication Study." Journal of Adolescent Health 54 (3 Suppl):S45-52. doi:

10.1016/j.jadohealth.2013.12.024.

LaChausse, R. G., K. R. Clark, and S. Chapple. 2014. "Beyond teacher training: the critical role of professional development in maintaining curriculum fidelity." Journal of Adolescent Health 54 (3 Suppl):S53-8. doi:

10.1016/j.jadohealth.2013.12.029.

Love is respect dot org. "Healthy relationships." Accessed 8 August 2019. https://www.loveisrespect.org/healthy-relationships/.

Lowe, Laura A., Chris D. Jones, and Leon Banks. 2007. "Preventing Dating Violence in Public Schools." Journal of School Violence 6 (3):69-87. doi: 10.1300/J202v06n03_05.

Magnani, R., K. Macintyre, A. M. Karim, L. Brown, P. Hutchinson, C. Kaufman, N. Rutenburg, K. Hallman, J. May, and A. Dallimore. 2005. "The impact of life skills education on adolescent sexual risk behaviors in KwaZulu-Natal, South 
Africa." Journal of Adolescent Health 36 (4):289-304. doi:

10.1016/j.jadohealth.2004.02.025.

Manaseri, H., D. Uehara, and K. Roberts. 2014. "Making Pono Choices: a collaborative approach to developing a culturally responsive teen pregnancy and sexually transmitted infections prevention curriculum in Hawai'i." Maternal and Child Health Journal 18 (10):2332-40. doi: 10.1007/s10995-013-1395-6.

Mantell, J. E., A. Harrison, S. Hoffman, J. A. Smit, Z. A. Stein, and T. M. Exner. 2006. "The Mpondombili Project: preventing HIV/AIDS and unintended pregnancy among rural South African school-going adolescents." Reproductive Health Matters 14 (28):113-22. doi: 10.1016/s0968-8080(06)28269-7.

Marques, M., and N. Ressa. 2013. "The Sexuality Education Initiative: a programme involving teenagers, schools, parents and sexual health services in Los Angeles, CA, USA." Reproductive Health Matters 21 (41):124-35. doi: 10.1016/s09688080(13)41702-0.

Mathews, Catherine, Sander Matthijs Eggers, Petrus J. de Vries, Amanda J. MasonJones, Loraine Townsend, Leif Edvard Aarø, and Hein De Vries. 2015. "Reaching the hard to reach: longitudinal investigation of adolescents' attendance at an after-school sexual and reproductive health programme in Western Cape, South Africa." BMC Public Health 15 (1):608. doi: 10.1186/s12889-015-1963-3.

McCarthy, Ona, Kenneth Carswell, Elizabeth Murray, Caroline Free, Fiona Stevenson, and V. Julia Bailey. 2012. "What Young People Want From a Sexual Health Website: Design and Development of Sexunzipped." Journal of Medical Internet Research 14 (5):e127. doi: 10.2196/jmir.2116.

McIver, Kate. 2010. "'Ur Choice': An innovative approach to relationships and sex education." Education and Health 28 (4):63-5.

McLeod, David Axlyn, Robin Jones, and Elizabeth P. Cramer. 2015. "An Evaluation of a School-based, Peer-facilitated, Healthy Relationship Program for At-Risk Adolescents." Children \& Schools 37 (2):108-16. doi: 10.1093/cs/cdv006.

Mellanby, A. R., F. A. Phelps, N. J. Crichton, and J. H. Tripp. 1995. "School sex education: an experimental programme with educational and medical benefit." BMJ 311 (7002):414-7. 
Mellanby, A. R., F. A. Phelps, and J. H. Tripp. 1996. A PAUSE: Adding Power And Understanding in Sex Education. The Project and Results: Research and Development Directorate, South and West NHS Executive.

Miller, E., S. Goldstein, H. L. McCauley, K. A. Jones, R. N. Dick, J. Jetton, J. G. Silverman, et al. 2015. "A school health center intervention for abusive adolescent relationships: A cluster RCT." Pediatrics 135 (1):76-85. doi: 10.1542/peds.2014-2471.

Miller, S, J Williams, S Cutbush, D Gibbs, M Clinton-Sherrod, and S Jones. 2015. "Evaluation of the Start Strong initiative: preventing teen dating violence and promoting healthy relationships among middle school students." The Journal of Adolescent Health 56 (2 Suppl 2):S14-9. doi: 10.1016/j.jadohealth.2014.11.003.

Murphy, Kylie A. 2011. "Skilling Adolescent Girls to Resist Abusive Relationship Dynamics: A Pilot Program Evaluation." The Australian Educational and Developmental Psychologist 28 (2):116-32. doi: DOI 10.1375/aedp.28.2.116.

Mustanski, B., G. J. Greene, D. Ryan, and S. W. Whitton. 2015. "Feasibility, acceptability, and initial efficacy of an online sexual health promotion program for LGBT youth: the Queer Sex Ed intervention." Journal of Sex Research 52 (2):220-30. doi: 10.1080/00224499.2013.867924.

New Zealand Police. "Loves-Me-Not." Accessed 8 August 2018. http://www.police.govt.nz/advice/personal-and-community-advice/schoolportal/resources/successful-relationships/loves-me-not

NJ Wise2Wait. "Institute for Relationship Intelligence." Accessed 8 August 2019. https://njwise2wait.org/institute-for-relationship-intelligence/.

Ott, Kate. 2016. "Sex and Candy: Unwrapping How We Define Sexuality." American Journal of Sexuality Education 11 (1):106-12. doi: 10.1080/15546128.2016.1146185.

Pacifici, C., M. Stoolmiller, and C. Nelson. 2001. "Evaluating a prevention program for teenagers on sexual coercion: A differential effectiveness approach." Journal of Consulting and Clinical Psychology 69 (3):552-9. doi: http://dx.doi.org/10.1037/0022-006X.69.3.552.

Peskin, M. F., R. Shegog, C. M. Markham, M. Thiel, E. R. Baumler, R. C. Addy, E. K. Gabay, and S. T. Emery. 2015. "Efficacy of It's Your Game-Tech: A ComputerBased Sexual Health Education Program for Middle School Youth." Journal of Adolescent Health 56 (5):515-21. doi: 10.1016/j.jadohealth.2015.01.001. 
Rijsdijk, Liesbeth E., Arjan ER Bos, Robert AC Ruiter, Joanne N. Leerlooijer, Billie de Haas, and Herman P. Schaalma. 2011. "The World Starts With Me: A multilevel evaluation of a comprehensive sex education programme targeting adolescents in Uganda." BMC Public Health 11 (1):334. doi: 10.1186/1471-2458-11-334.

Rosen, Brittany, Elisa Beth McNeill, and Kelly L Wilson. 2014. "Would you Rather (WYR), with a sexual health twist!". The Health Educator 46 (1).

Schmidt, Sara C, Abraham Wandersman, and Kimberly J Hills. 2015. "Evidence-Based Sexuality Education Programs in Schools: Do They Align with the National Sexuality Education Standards?". American Journal of Sexuality Education 10 (2):177-95. doi: 10.1080/15546128.2015.1025937.

Scott, Mindy E, Kristin Anderson Moore, Alan J Hawkins, Karin Malm, and Martha Beltz. 2012. "Putting Youth Relationship Education on the Child Welfare Agenda: Findings from a Research and Evaluation Review." Child Trend Publications:http://www.childtrends.org/wp-content/uploads/2013/06/247RelationshipEducFullRpt.pdf Last accessed 8 August 8.

Scull, Tracy M., Christina V. Malik, and Janis B. Kupersmidt. 2014. "A Media Literacy Education Approach to Teaching Adolescents Comprehensive Sexual Health Education." The journal of media literacy education 6 (1):1-14.

Silliman, Benjamin. 2003. "Building healthy marriages through early and extended outreach with youth." Journal of Psychology and Theology 31 (3).

Smylie, Lisa, Eleanor Maticka-Tyndale, and Dana Boyd. 2008. "Evaluation of a schoolbased sex education programme delivered to Grade Nine students in Canada." Sex Education 8 (1):25-46. doi: 10.1080/14681810701811795.

Spear, Caile, Michael Young, and George Denny. 1997. "Field Testing of an Abstinence-Based Sexuality Education Program for Upper Elementary School Students." Journal of Health Education 28 (6):335-44. doi: 10.1080/10556699.1997.10608609.

Stephenson, J. M., V. Strange, S. Forrest, A. Oakley, A. Copas, E. Allen, A. Babiker, et al. 2004. "Pupil-led sex education in England (RIPPLE study): clusterrandomised intervention trial." Lancet 364 (9431):338-46. doi: 10.1016/s01406736(04)16722-6.

Stevens, Sally, Elisabeth Morgan Thompson, Jenna Vinson, Alison Greene, Claudia Powell, Adela C. Licona, and Stephen Russell. 2013. "Informing sexuality 
education through youth-generated anonymous questions.". Sex Education 13 (sup1):S84-S98. doi: 10.1080/14681811.2013.781020.

Tender. "The Tender Healthy Relationships Project ", Accessed 8 August 2019. http://tender.org.uk/what-we-do/schools-programme/

Tharp, A. T., T. Burton, K. Freire, D. M. Hall, S. Harrier, N. E. Latzman, F. Luo, P. H. Niolon, M. Ramirez, and K. J. Vagi. 2011. "Dating Matters: strategies to promote healthy teen relationships." Journal of Women's Health 20 (12):1761-5. doi: 10.1089/jwh.2011.3177.

The 5 Love Languages ${ }^{\circledR}$. "A Teen's Guide to the 5 Love Languages." Accessed 8 August 2019. https://www.5lovelanguages.com/book/a-teens-guide-to-the-5love-languages/.

Whitten, Krystle M., and Isaac Burt. 2015. "Utilizing Creative Expressive Techniques and Group Counseling to Improve Adolescents of Divorce Social-Relational Capabilities." Journal of Creativity in Mental Health 10 (3):363-75. doi: 10.1080/15401383.2014.986594.

Wight, D, and H Dixon. 2004. "SHARE: The rationale, principles and content of a research-based teacher-led sex education programme." Education and Health 22 (1):3-7.

Wolfe, D. A., C. Crooks, P. Jaffe, D. Chiodo, R. Hughes, W. Ellis, L. Stitt, and A. Donner. 2009. "A school-based program to prevent adolescent dating violence: a cluster randomized trial." Archives of Pediatrics and Adolescent Medicine 163 (8):692-9. doi: 10.1001/archpediatrics.2009.69.

Women's Aid. "The Expect Respect Educational Toolkit." Accessed 10 August 2018. https://www.womensaid.org.uk/what-we-do/safer-futures/expect-respecteducational-toolkit/. 


\title{
Exploring the content and delivery of relationship skills education programmes for adolescents: a systematic review
}

\author{
Astrid Janssens*a, b, Sharon Blake ${ }^{\mathrm{b}}$, Matt Allwood ${ }^{\mathrm{c}}$, Jan Ewings ${ }^{\mathrm{d}}$, Anne \\ Barlow $^{\mathrm{d}}$
}

${ }^{a}$ User Perspectives, Institute of Health Research, University of Southern Denmark, Denmark, ${ }^{b}$ Child Health, University of Exeter Medical School, University of Exeter, UK; ${ }^{c}$ Department of Psychiatry, University of Oxford, Oxford, UK; ${ }^{d}$ School of Law, University of Exeter, $U K$

*Corresponding Author: Astrid Janssens, Associate Professor, User Perspectives, Institute of Health Research, University of Southern Denmark; Honorary Associate Professor, Child Health, University of Exeter Medical School.

J. B. Winsløws Vej 9B, 1. Sal, 5000 Odense C, DENMARK, Tel: +45 65503069 AJanssens@ health.sdu.dk Twitter: @ avajanssens ORCID: 0000-0001-8419-0937

\section{Funding details}

This work was supported by an alumnae donation to the University of Exeter from Baroness Shackleton of Belgravia VLO.

\section{Disclosure statement}

The project was supported by an alumna donation from Baroness Shackleton of Belgravia VLO to the University of Exeter. During the project, authors AJ, SB, and JE were supported by the research grant received. The funder had no role in study design, data collection, data analysis, interpretation of data, or writing of the paper. The views and opinions expressed therein are those of the authors and do not necessarily reflect 
those of the funder. The authors declare that there are no further conflicts of interests to declare.

\section{Data availability statement}

The authors confirm that the data supporting the findings of this study are available within the article and its supplementary materials.

\section{Acknowledgements}

Our thanks go to Fiona Shackleton who funded this research, members of the Evidence Synthesis Team at the University of Exeter Medical School who advised the design of the search strategy and Abigail Woodley for assistance in running the database searches. The authors would like to thank Ebony Tregent and Tom Reed for assisting the research team with the online searches for programme content. 